\title{
Aliphatic hydrocarbons and triterpenes of the Congo deep sea fan
}

\author{
Méjanelle Laurence ${ }^{1,{ }^{*}}$, Rivière Béatrice ${ }^{1}$, Pinturier Laurence ${ }^{2}$, Khripounoff Alexis ${ }^{3}$, Baudin François ${ }^{4}$, \\ Dachs Jordi ${ }^{5}$
}

${ }^{1}$ Sorbonne Universités, UPMC-Univ. Paris 06, CNRS, Laboratoire d'ECObiogéochimie Benthique, UMR 8222, 18 Avenue du Fontaulé, 66650 Banyuls Sur Mer, France

2 Total E\&P, Norge AS, Finnestadveien 44, 4029 Stavanger, Norway

${ }^{3}$ Ifremer Centre Bretagne, Institut Carnot-Ifremer-EDROME, Laboratoire Environnement Profond,

(REM-EEP-LEP), 29280 Plouzané, France

${ }^{4}$ Sorbonne Universités, UPMC-Univ. Paris 06, CNRS, Institut des Sciences de la Terre de Paris, 4

place Jussieu, 75005 Paris, France

${ }^{5}$ Department of Environmental Chemistry, Institute of Environmental Assessment and Water Research

(IDAEA-CSIC), Barcelona, Catalonia, Spain

*Corresponding author : Laurence Méjanelle, email address : laurence.mejanelle@upmc.fr

\begin{abstract}
:
Hydrocarbons were analyzed in sediments from the Congo River deep-sea fan, from the Congo River, and in sinking particles collected by sediment traps $40 \mathrm{~m}$ above the sediment. Studied sites encompassed three lobes of decreasing age of formation along the canyon: sites $A, F$ and $C$ and $a$ another lobe system, disconnected from the active channel since $4 \mathrm{ka}$, Site E. Terrestrial long-chain odd $\mathrm{n}$-alkanes were dominant in all sediments of the lobe system. Unsaturated terpenoids sourced by higher plants, such as gammacerene, lupene, ursene and oleanene, were also detected. At site C, characterized by high accumulation rates $(10-20 \mathrm{~cm} \mathrm{yr}-1)$, the organic matter spends less time in the oxic layer than at other sites and high phytadiene concentrations (10 to $17 \mu \mathrm{g} \mathrm{gOC}-1)$ evidenced recent terrestrial and phytoplanktonic remains reworked in anaerobic conditions. In these sediments, organic carbon-normalized concentrations of terrestrial alkanes and terpenoids were several fold higher than in the lobe sediments with lower accumulation rates (sites A and F), arguing for a more rapid degradation of terrestrial hydrocarbons than bulk organic carbon in the first steps of pre-diagenesis. Ample variations in the contributions of biomarkers from higher plants, ferns, bacteria and angiosperms, indicate an heterogeneous contribution of the soil and vegetation detritus delivered to the Congo lobe sediments. Lower concentrations in terrestrial hydrocarbons at site E, $45 \mathrm{~km}$ away from the active canyon, indicated that river particles are still admixed to the dominant marine organic matter. Diploptene and hop7(21)ene have a dual origin, from terrestrial and marine microorganisms. Scatter in their relationship to gammacerene argues for a contribution of marine microorganisms, in addition to soils-sourced microorganisms. The close distribution patterns of diploptene, hop-21-ene, hop-7(21)ene and neohop13(18)-ene is in line with the hypothesis of sequential clay-catalyzed isomerisation of bacterial hopenes. Terrestrial biomarker accumulation fluxes at site $\mathrm{C}$ are one order of magnitude higher than vertical pelagic flux, demonstrating the magnitude of the inputs delivered through turbiditic transport in the submarine canyon. Crude oil contamination was evidenced at the disconnected site E (UCM, C21 to
\end{abstract}


C26 tricyclic diterpanes, CPI) and, in smaller amounts, in some sediments from sites A and C. It may be related to marine crude oil extraction and transport. A short-chain mode of alkanes with an even predominance is evidenced in sediments of the lobe complex and likely sources, crude oil, microorganisms and ferns, are discussed.

Keywords : Congo fan, hydrocarbons, NAH, hopanes, hopenes, sediments, turbidite system 


\section{Introduction}

The effort to quantitatively understand and predict the carbon cycle includes the assessment of the inventory of marine reservoirs of organic carbon and the prediction of its oxidation and transfer back to atmospheric $\mathrm{CO}_{2}$. However part of the terrestrial organic carbon escapes degradation and is buried in sedimentary horizons where no more oxidation occurs. Marine sediments are among the largest sinks of organic carbon, and half of this organic carbon reservoir is sourced by terrestrial plants and organisms (Blair and Aller, 2012; Burdige, 2005; 2007). This preserved organic carbon accounts for less than half the rivers inputs (Burdige, 2007 and references therein) which pictures the ocean margins as efficient in both remineralizing terrestrial organic matter and sequestering it (Middelburg et al., 1993). The organic carbon budget bridges processes on different times scales. The water column biogeochemical cycling and early diagenesis processes integrate annual to decadal time scales. In contrast, the cycle of organic carbon that is ultimately preserved in marine sediments as geopolymers, kerogen or source rocks eroded from the continent, may exert feedbacks on atmospheric $\mathrm{CO}_{2}$ over thousand years to geologic time scale, with enhanced carbon burial during low sea level glacial ages (Cartapanis et al., 2016).

The Congo River (ex-Zaire) has a large intertropical watershed mainly covered by C3 rain forest vegetation. It delivers a large flux of higher plant debris and fine particles eroded from soil to the 
Atlantic Ocean, while it carries a minor contribution of riverine planktonic organic matter (Spencer et al., 2012). The particulate organic carbon exported to the Atlantic Ocean by the Congo River accounts for an input of $2 \mathrm{Tg}$ organic carbon per year (Coynel et al., 2005). The Congo River is connected to a sinuous submarine canyon that starts within the river mouth, deeply incises in the shelf and slope and further extends in the deep basin through an active channel-levees-lobe system. The active terminal lobe complex is located at $4750 \mathrm{~m}$ depth, $760 \mathrm{~km}$ away from the river mouth (Savoye et al., 2009; Vangriesheim et al., 2009).

Overload of river sediments and sliding of sediment at the canyon head can initiate energetic gravity currents that transport most of the river particles to the terminal lobe complex. Besides terrestrial organic matter, sediments of the Congo-Angola margin also comprise a remarkable contribution of marine organic matter sourced by the coastal upwelling North and South the Congo River plume and within the plume itself (Schefuß et al., 2004). As a result, the gravity currents may transport an admixture of organic carbon sourced by this coastal autochthonous production together with the river inputs. Times series studies have captured very energetic turbidity events upstream the terminal lobe complex (Khripounoff et al., 2003; Vangriesheim et al., 2009). For example, a turbiditic event in 2001 caused a massive particle flux within the canyon but also spilled over its edge thereby yielding a high pulse of terrestrial clay on the levee, $18 \mathrm{~km}$ away from the canyon channel, in an area otherwise characterized by marine pelagic particle flux (Khripounoff et al., 2003). In 2004, two intense events were recorded by intense peaks in turbidity and in particle flux, and by mooring breaking (Vangriesheim et al., 2009). When reaching the terminal lobe system, even though the current looses velocity, it can still deliver intense particle flux (Vangriesheim et al., 2009). Besides turbitic currents smaller pulses in particle flux with no current increase were also recorded, and indicate local sliding of sediment accumulated on the walls or terraces on the sides of the channel (Vangriesheim et al., 2009).

The Congolobe project aims at studying the geology, geochemistry and ecology of the Congo terminal deep sea fan system (Rabouille et al., 2016), a hotspot of terrestrial carbon burial (Baudin et al., 2017 b). The sediments of the lobe complex are organic-rich silts and silty-clays, their $\mathrm{C} / \mathrm{N}$ and $\delta^{13} \mathrm{C}$ values indicated that 70 to $80 \%$ of the OM was terrestrial in origin (Baudin et al., 2010; Stetten et al., 2015), and are mostly composed by river particles conveyed from the Congo mouth by turbiditic currents. Sediment palynofacies revealed predominant well preserved particles derived from plant structures. In addition, amorphous organic matter was relatively more abundant in the studied levee whereas the denser well preserved wood fragments and transparent intact phytoclasts were enriched in the channel sediment, suggesting a general sorting of particles according to the density of particle (Schnyder et al., this volume). Palynofacies also evidenced a vertical gradient in the upper $20 \mathrm{~cm}$ of the cores. Amorphous organic matter is relatively enriched upcore with respect to denser terrestrial components, which further supports hydraulic sorting of particles in the turbiditic deposits.

Molecular geochemistry allows complementary evidences to bulk geochemical information. Terrestrial molecular biomarkers fall into extractable lipids or non extractable macromolecules. Typical terrestrial biomarkers such as lignin phenols for instance, have revealed selective sorting of higher plant debris and soil particles (Gordon and Goñi, 2004; Rezende et al., 2010). Branched glycerol dialkyl glycerol tetraethers (DGDT) are used to trace soil inputs to aquatic sediments (Kim et al., 2012; Lopes dos Santos and Vane, 2016). Even if lipids comprise less than $1 \%$ of the bulk terrestrial organic pool, terrestrial lipid biomarkers are routinely used to detect variations in terrestrial inputs and in their preservation in sediments. Odd long-chained $\left(\mathrm{C}_{25}-\mathrm{C}_{35}\right)$ alkanes are higher plant biomarkers resistant to degradation and are commonly used as vascular plant proxy, in present day environments as well as in paleoreconstruction studies (Castañeda et al., 2011; Gogou et 
al., 2000; Mangelsdorf et al., 2000; Romero-Viana et al., 2012). A 3 year survey of $n$-alkanes in suspended particles from the Congo River showed that they integrate the catchment signal with minimal seasonality (Hemingway et al., 2016).

The present contribution examines the hydrocarbon composition of sediments of the lobe complex, of Congo River sediments and of sediment traps in order to complement bulk proxies and palynofacies evidences. The present contribution aims at bringing information on the source of the organic matter preserved in the lobe sediments. It questions whether the spatial distribution of terrestrial hydrocarbon biomarkers reflects the variability evidenced by palynofacies. Concentrations of both aliphatic and terpenic hydrocarbons in recent marine sediments are very seldom reported in the literature and concentrations of both aliphatic and terpenic hydrocarbons presented here provides original reference data for this region, displaying uncommon terpene abundances. In addition fluxes have seldom been reported previously. Comparing sedimentary mass accumulation rates and water column fluxes of aliphatic and terpenic hydrocarbons brings new understanding of the importance of terrestrial hydrocarbon inputs.

Five sites representative of an upstream-downstream gradient in the lobe complex, including both the active lobe system and an abandoned lobe, and a site in the Congo River were selected for sedimentary hydrocarbon molecular study. This sample set has been previously characterized for grain size, organic carbon concentration $(\mathrm{OC}), \delta^{13} \mathrm{C}, \mathrm{C} / \mathrm{N}$ ratio, Rock-Eval and other geochemical approaches (Baudin et al., 2017 a; Stetten et al., 2015; Schnyder et al., this volume). Particles collected by sediment trap moored $40 \mathrm{~m}$ above the lobe sediment beds were also analyzed to understand the contribution of sinking particles.

\section{Material and methods}

\subsection{Sampling strategy}

The samples were collected during two cruises that took place in 2011 on the RV Pourquoi Pas? The first one, WACS (Olu, 2011) was conducted in February 2011 and the second one, CONGOLOBE, was performed between December 2011 and January 2012 (Rabouille et al., 2011). The objectives of the Congolobe project, the sampling rationale and geological and geochemical characteristics of the studied sites are detailed in Rabouille et al. (2016). The distal lobe complex of the active canyon is the area where the canyon depth progressively decreases and the sediments accumulate, as shown by the maxima in sediment accumulation rate (Rabouille et al., 2016). The lobe complex comprises 5 prograding lobes partly stacked one over the other and having increasing age of formation, from ca 4 ka for the most upstream and oldest lobe (numbered lobe 1, Figure 1) to present time for the most distal and youngest lobe (numbered lobe 5, Figure 1) (Bonnel, 2005; Dennielou et al. this volume; Rabouille et al., 2016). In addition, the high resolution bathymetric study showed an abondoned channel that led to the lobe complex in the past, on the northern levee. This presently inactive channel departs from the active one upstream from site A. Close to the area where both channels depart one from another, the presently inactive one is $25 \mathrm{~m}$ deep and $1000 \mathrm{~m}$ wide and it extends to lobe 3 . The channel that is currently active is $45 \mathrm{~m}$ deep and $1400 \mathrm{~m}$ wide and connects to the more recent lobe 5 . When turbidite particles spill over the levees of the active channel, they may fill the inactive channel, and create the smoothed morphology of that canyon while filling it. The morphology of this canyon may also allow some particle transport to lobe 3 . 
Table 1 reports the locations and depths of the analyzed sample set. Sites A, F and C are located along an upstream - downstream gradient along the active southern channel. Site $A$ is located in lobe 2 (A), where the canyon is a $45 \mathrm{~m}$ deep channel in which the sediment core CoL-A-MTB03 was recovered. This core was collected on the southern levee displaying gentle flanks (Rabouille et al., 2016). Site $F$ is located at the onset of lobe $4,40 \mathrm{~km}$ downstream of site $A$ and the sediment core CoL-F-MTB-04 was collected on the northern levee of this site. At site $F$, the canyon is a $45 \mathrm{~m}$ deep and $2500 \mathrm{~m}$ wide channel. Site $\mathrm{C}$ is located $25 \mathrm{~km}$ downstream of site $\mathrm{F}$, at the distal part of the lobe 5 , where the canyon structure fades into a $11 \mathrm{~m}$ deep channel, as a result of the accumulation of recent particle deposits. At this site, the sediment core CoL-C-MTB-06 was collected on the levee and CoL-CMTB-11 on the channel. CoL-B-MTB-12 was sampled on lobe 3 at site B, located on the northern levee in the vicinity of the inactive channel. At the coring location the presently inactive channel leading to lobe 3 is only a few meters deep. Site $E$ characterizes an abandoned northern lobe complex, $45 \mathrm{~km}$ north of the active channel that receives little turbiditic matter since at least $4 \mathrm{ka}$ BP (Rabouille et al., 2016; Stetten et al., 2015). This site refers to conditions where mainly pelagic inputs recently build up the sediments, as opposed to the other sites where turbidites are the main deposit types. The sediment core CoL-E-MTB-14 was collected at this site.

In order to characterize the Congo River particulate inputs, sediments from the river floodplain were analyzed (Table 1). They were collected at three sites at the Malebo Pool, permanently flooded, inundated during high discharge months, and recently exposed, and were donated from $\mathrm{H}$. Talbot and R. Spencer (Talbot et al., 2014, supplementary Table 2). At these sites the particulate organic carbon composition compares well to that in the estuary and these 3 river sediments are considered as representative of the Congo particulate export to the Atlantic (Spencer et al., 2012).

In order to characterize the vertical rain of pelagic particles, a limited set of sediment trap samples from 3 sites were considered (Table 1). Two sediment traps were located at a mid distance between the canyon head and the lobe complex, one is located $10 \mathrm{~km}$ north of the canyon channel and is located above a large cold seep pockmark (samples TrR1 and TrR2), the other is above the canyon itself ( $\operatorname{TrC} 1, \operatorname{TrC} 2$ and $\operatorname{TrC} 4)$. The third trap was moored at the entrance of the lobe complex above the site $\mathrm{A}$ (TrA1 and TrA2).

\subsection{Hydrocarbon molecular analyses}

Known amounts of $\mathrm{C}_{24} \mathrm{D}_{50}$ were added to the lyophilised samples prior to extraction as a surrogate for non aromatic hydrocarbons. The lyophilised sediment samples (ca. 0.2 to 6 g d.w.) were extracted using accelerated solvent extraction. The samples were homogenised with diatomeous powder previously combusted at $450^{\circ} \mathrm{C}$ and sequentially extracted using accelerated solvent extraction (Dionex ASE 350). The first extraction, with acetone at $100^{\circ} \mathrm{C}$ and 1500psi for 1 static cycle of $5 \mathrm{~min}$. and $60 \%$ of flush, was followed by 3 static cycles of 5 min. with acetone/dichloromethane $(1: 1)$ at $100^{\circ} \mathrm{C}$ and under a pressure of 140 bars. The sequence was previously optimized using coastal sediments to ensure no crosscontamination. The lipid extracts were treated with acid-activated copper to remove elemental sulfur. The extracts were concentrated using rotary evaporation, solvent exchanged to iso-octane and concentrated down to $200 \mu \mathrm{l}$. They were purified into different fractions on a dual silica/alumina column made of $5 \mathrm{~g}$ of silica deactivated at $5 \%$ and $3 \mathrm{~g}$ of alumina deactivated at $3 \%$. The first fraction, eluded by $25 \mathrm{ml}$ of hexane, contained the aliphatic and cyclic hydrocarbons. 
This fraction was first analyzed for aliphatic compounds by gas chromatography (GC) coupled to a flame ionization detector (FID) equipped with a DB-5MS capillary column (J\&W, $30 \mathrm{~m} \times 0.249 \mathrm{~mm}$ i.d. $\times 0.25 \mu \mathrm{m}$ thick phase film). The carrier gas was helium at a pressure of $110 \mathrm{kPa}$. The oven temperature, initially at $60^{\circ} \mathrm{C}$ was brought to $100^{\circ} \mathrm{C}$ at a rate of $25^{\circ} \mathrm{C} / \mathrm{min}$, then to $310^{\circ} \mathrm{C}$ at a rate of $2^{\circ} \mathrm{C} / \mathrm{min}$. The final isotherm of $310^{\circ} \mathrm{C}$ was held for 60 minutes. The FID was kept at $330^{\circ} \mathrm{C}$. Aliphatic hydrocarbons were quantified relatively to the internal standard added prior to extraction. For river and trap samples the quantity of available material $(0.2$ to $1 \mathrm{~g}$ ) did not allow a proper quantification by GC-FID. These samples were quantified by GC-Mass Spectrometry (GC-MS) on an Agilent 6890 Series GC system coupled to an Agilent 5973 Network Mass Selective Detector. A DB-5MS capillary column (Agilent DB5, $30 \mathrm{~m} \times 0.25 \mathrm{~mm}$ i.d. $\times 0.25 \mu \mathrm{m}$ thick phase film) was used. The carrier gas was helium at a flow of $1.2 \mathrm{ml} / \mathrm{min}$. The initial oven temperature of $60^{\circ} \mathrm{C}$ was held for 5 minutes, then brought from $60^{\circ} \mathrm{C}$ to $160^{\circ} \mathrm{C}$ at a rate of $25^{\circ} \mathrm{C} / \mathrm{min}$, then increased to $310^{\circ} \mathrm{C}$ at a rate of $3^{\circ} \mathrm{C} / \mathrm{min}$ with a final isotherm of 10 minutes. Full acquisition program scan (from 40 to 600 amu) under electron impact ionization at $70 \mathrm{eV}$ was used. Individual hydrocarbons were quantified relatively to the surrogate $\left(C_{24} D_{50}\right)$ and corrected with relative response factors (RRFs). Calibration solutions containing 25 target $n$-alkanes (prepared from Alkane mix 10, Dr Erhenstorfer $\mathrm{GmD}$ ), chosen to bracket the sample concentrations, were used to derive the RRFs of the analytes. Carbon Preference Index (CPI) was calculated as:

$$
\mathrm{CPI}_{24-34}=\frac{1}{2} \times\left(\frac{\left(\mathrm{C}_{25}+\mathrm{C}_{27}+\mathrm{C}_{29}+\mathrm{C}_{31}+\mathrm{C}_{33}+\mathrm{C}_{35}\right)}{\left(\mathrm{C}_{24}+\mathrm{C}_{26}+\mathrm{C}_{28}+\mathrm{C}_{30}+\mathrm{C}_{32}+\mathrm{C}_{34}\right)}+\frac{\left(\mathrm{C}_{25}+\mathrm{C}_{27}+\mathrm{C}_{29}+\mathrm{C}_{31}+\mathrm{C}_{33}+\mathrm{C}_{35}\right)}{\left(\mathrm{C}_{26}+\mathrm{C}_{28}+\mathrm{C}_{30}+\mathrm{C}_{32}+\mathrm{C}_{34}+\mathrm{C}_{36}\right)}\right)
$$

Hopanes and other triterpenes were semi-quantified by integrating peaks on the ion current at $\mathrm{m} / \mathrm{z}$ 191. The major hopanoid, hop-17(21)-ene, was quantified by GC-FID, and the other triterpene abundances were calculated by relating their area to that of the hop-17(21)-ene. In a few samples, hop-17(21)-ene could not be quantified on the GC-FID trace. In those few samples, the hopane abundances were calculated by relating their area to that of the $n-C_{31}$ $n$-alkane, and correcting with response factors determined from the samples where both $n$ $C_{31}$ and hop-17(21)-ene were unequivocally quantified by GC-FID responses.

Procedural blanks were processed and analyzed. They were clear of contamination. The method was also tested for reproducibility and repeatability. The disparity was less than $5 \%$.

Sedimentary accumulation fluxes of the given hydrocarbons were calculated as :

$$
\Phi_{\mathrm{alk}}=\mathrm{C}_{\mathrm{alk}} \times \mathrm{AR} \times \mathrm{d} \times(1-\mathrm{p}) \times 10^{4}
$$

With $\Phi_{\text {alk }}$ the mass accumulation rate of the hydrocarbon in $\mathrm{ng} \mathrm{m}^{-2} \mathrm{yr}^{-1}, \mathrm{C}_{\mathrm{alk}}$ the concentration of a given hydrocarbon in $\mathrm{ng} . \mathrm{g}^{-1}$ of dry weight, AR the sediment accumulation rate in $\mathrm{cm} \mathrm{yr}^{-1}, \mathrm{~d}$ the sediment density in $\mathrm{g} \mathrm{cm}^{-3}, \mathrm{p}$ the sediment porosity.

\section{Results}

\section{$\underline{3.1 n \text {-alkanes molecular profiles and concentrations }}$}


A total of $31 n$-alkanes ranging from $\mathrm{C}_{10}$ to $\mathrm{C}_{40}$, and 8 isoprenoid hydrocarbons were identified and quantified in the samples. The dominant biomarkers in most sediments of the lobe complex sediments are a suite of $n$-alkanes dominated by high-MW compounds $\left(>C_{24}\right)$ with predominance of odd over even carbon chain alkanes (CPI values from 4.0 to 9.6) (Figure 2, Table S1 supplementary material). They derive from higher plant waxes (Table 2). Their concentrations in the lobe sediments varied from 50 to $6070 \mathrm{ng} \mathrm{gDw}^{-1}$, from 320 to $1150{\mathrm{ng} \mathrm{g} \mathrm{DW}^{-1}}^{-1}$ in Congo River banks and from 470 to $2040 \mathrm{ng} \mathrm{g} \mathrm{DW}^{-1}$ in sediment traps. Their range compares well with other River deltas (Table 3). The three sediments from the Congo River show an identical hydrocarbon composition, maximizing at $n-C_{29}$, and with the $n-C_{23}$ to $n-C_{35}$ mode accounting from 91 to $95 \%$ of total non cyclic hydrocarbons. These patterns are consistent with the molecular composition described for suspended particles in the Congo River (Hemingway et al., 2016). This strong higher plant signature is mirrored in alkane molecular patterns from many of the studied sediments: the levee of site $A$, the channel at site $C$, and in the deeper part of the site $E$ ( $>10 \mathrm{~cm}$ horizons), confirming that the Congo River is the primary supply of the organic matter accumulated in the lobe complex (Figure 3 ). In the sinking particles collected by sediment traps, the higher plant fingerprint is faint at the Regab site, located away from the active channel, marked at the canyon site, and variable at site A (Figure 3).

In sediments from the channel of site $A$, the levee of site $F$, the levee and upper horizons of the channel at site $\mathrm{C}$ and of site $\mathrm{E}$, the terrestrial imprint co-occurs with a low molecular weight mode of $n$-alkanes, with even predominance maximizing at $n$ - $C_{14}$ and $n-C_{16}$ (Figure 2, right middle and bottom panels). The phytoplanktonic biomarker $n-C_{17}$ indicates recent input of phytoplanktonic biomass (Table 2; Marty et al., 1994). Its higher contribution in sediment trap particles than in sediments and soils underlines the predominantly marine origin of the sinking particles, in line with Rock-Eval assessment (Baudin et al., 2017 a).

Chromatographically unresolved hydrocarbons were detected in 12 samples. The unresolved complex mixture (UCM), potentially composed of over 250000 cyclic and branched hydrocarbons (Sutton et al., 2005) bring evidence for the occurrence of petrogenic hydrocarbons (Table 2). UCM concentration was the highest in the surface sediments of site $\mathrm{E}\left(10500 \mathrm{ng} \mathrm{\textrm {DDW } ^ { - 1 }}{ }^{-1}\right.$, and took higher values in some sediments of the sites $\mathrm{A}$ and $\mathrm{B}$ (up to 
$8000 \mathrm{ng} \mathrm{gDW}^{-1}$ and up to $1500 \mathrm{ng} \mathrm{gDW}^{-1}$, respectively). The ratio of UCM / resolved hydrocarbons take values of 13 and 7 indicating that the oil input is non degraded.

Three phytadiene isomers were the dominant isoprenoids in the vast majority of sediment samples, but they were absent in river sediments and nearly absent in sinking particles (Figure 5). The concentrations of the three isomers were similar and that of the third one took a maximum value $202 \mathrm{ng} \mathrm{gDW}^{-1}$ in the surface sediment of the levee at site $\mathrm{C}$, and of $1 \mathrm{ng}$ $\mathrm{gDW}^{-1}$ in the sole trap sample where phytadienes could be identified.

\subsection{Triterpene molecular profiles}

Substantial amounts of triterpenes were present in the sediment extracts from the terminal lobe, in particular at site $C$. The hopane and hopene mass spectra interpretation was inferred from retention times and published spectra. Representative $m / z=191$ hopanograms and mass spectra of the major hopanoids are presented in the supplementary material (Figures S2, S3, S4 and S5).

Triterpene distribution patterns within the lobe complex sediments shared common features such as the predominance of $C_{30}$ and $C_{31}$ hopanes in the $17 \beta(H), 21 \beta(H)(\beta \beta)$ and $17 \beta(H), 21 \alpha(H)(\beta \alpha)$ configurations and of unsaturated hopanoids (Figures 6 et 7). Both characteristics are a clear signature of recent immature organic matter, as opposed to oil contamination. Hopane and $C_{31}$ homohopane having retained their precursor $\beta \beta$ configuration are abundant in terrestrial clays and sediments (Kvenvolden at al., 1990; Marynowski et al., 2007a). In the lobe complex sediments, they likely traced terrestrial inputs (Figure 7). A few samples showed contrasting composition: in surficial sediments (0$0.5 \mathrm{~cm}$ and 0.5 -and $1 \mathrm{~cm}$ ) of the disconnected $\mathrm{E}$ site, tricyclic diterpanes with 20, 21, 23, 24 and 25 carbon atoms were the dominant homologues, and hopenes were less abundant or non detected (Figure 6, Figure S2 in supplementary material). Tricyclic diterpanes have been described as the major homologues in saline lacustrine and marine crude oils (Tao et al., 2015), and their occurrence points to oil contamination of site E surficial sediment, in agreement with the UCM concentrations and CPI values. However the hopane profile in the lobe complex sediments did not show the characteristics of a mature oil ( $\alpha \beta$ and moretane 
dominance over $\beta \beta$-hopanes), as the hopene profile was the same as in the other noncontaminated sites, and as in the non-contaminated deeper horizons at site E (hop-17(21)ene, $\beta \beta-C_{30}$ hopane and $\beta \beta-C_{31}$-homohopane (Figure 6).

In most lobe sediments, hop-17(21)-ene, $\beta \beta$-hopane and diploptene (hop-22(29)-ene) were the dominant homologues (Figures 9 and 10). Diploptene is present in various types of bacteria and is related to the membrane constituent bacterihopanetetraol (Table 2). In contemporary sediments, its diagenesis starts with double bond migration into hop-21-ene, then into hop-17(21)-ene, and further proceeds by rearrangement and migration of the methyl at C-18 to the position C-17 forming norneohop-13(18)-ene (Simoneit, 2005). In the present sample set, the four isomers were detected in variable proportions. Hop-17(21)-ene prevailed in most sediments, in particular at the site $C$, and also in the sinking particles collected by sediment traps. Hop-17(21)-ene concentrations were from non detected to $9 \mathrm{ng}$ $\mathrm{gDW}^{-1}$ in the Congo River sediments, maximized at $335 \mathrm{ng} \mathrm{g}_{\mathrm{DW}}^{-1}$ in some sediments of the site $\mathrm{C}$ and varied from non detected to $303 \mathrm{ng} \mathrm{gDW}^{-1}$ in the sediment trap samples. In river samples and in a few samples (site A levee, site C surficial layers) diploptene was equally prominent in the $\mathrm{m} / \mathrm{z} 191$ fragmentograms. Diploptene concentrations reached $25 \mathrm{ng} \mathrm{g}_{\mathrm{DW}}{ }^{-1}$ in the Congo River sediments, $294 \mathrm{ng} \mathrm{g}_{\mathrm{DW}}{ }^{-1}$ in some sediments of the site $\mathrm{C}$ and $215 \mathrm{ng} \mathrm{g}_{\mathrm{DW}}{ }^{-1}$ in the sediment trap samples. Neohop-13(18)-ene seldomly prevailed, for instance in surficial sediment of the levee of the site A (Figure 6). A $C_{27}$ 22,29,30trisnorhop-13(18)-ene was also detected in most samples (Figures S3 and S4, supplementary material).

Gammacerene was the most abundant non-hopanoid triterpene in the lobe sediments. It differs from hopanoid by a six-, instead of 5-, membered $E$ ring. Other non-hopanoid triterpenes produced by higher plants were detected in the lobe sediments: oleanene, lupene, ursene and fernenes (Figure 6). The ursane and oleanane skeletons derive from $\alpha$ and $\beta$-amyrins and are the most frequently encountered in recent sediments (Simoneit, 2005). Oleanene accounted for a higher portion of triterpenes at the levee of site $A$, and was less abundant at the other sites (Figure 6). Even though bulk indices showed a rather homogeneous, mostly terrestrial, organic matter at the sites $A, F$ and $C$ of the lobe, the contribution of vascular plant and soil bacterial biomarkers may differ by as much as one order of magnitude in the terminal lobe sediments (Figures 2, 7 and 8). Oleanene, ursenes, 
and hop-17(21)-ene are reported in shelf sediments at other locations worldwide or in terrestrial clays (Brassell, 1984; Ten Haven and Rullkötter, 1989; van Dongen et al., 2006; Marynowski et al., 2007a). $\beta \beta$-homohopane is also one of the dominant terpenoid in immature terrestrial organic matter (Kvenvolden et al., 1990). The saturated homologues of higher plant triterpenes were not detected, nor gammacerane, bringing another evidence of the immaturity of the soil and plant organic matter present in the sediments. Pearson correlations show that gammacerene is related to the bulk terrestrial indicator $\delta^{13} \mathrm{C}$, suggesting that it quantitatively contributed to the bulk terrestrial matter, while oleanene and fernenes did not, and may represent a less abundant higher plant contribution (Table S2, Supplementary material). Des-A-triterpenoids are formed by A-ring degradation under anoxic conditions (van Bree et al., 2016). They are detected in low levels in the terminal lobe system and indicate the occurrence of degraded C3/C4 plants (Table S1 supplementary material).

Steranes, sterenes and diasterene showed a minor contribution to the Congo River and lobe sediments. Higher $\mathrm{C}_{29}$ sterene concentrations characterized the sediment trap samples. They more probably stem from the degradation of higher plant and phytoplankton sterols.

\section{Discussion}

\subsection{Organic matter sources and degradation by microorganisms, spatial heterogeneity}

Sedimentary hydrocarbons in the terminal lobe complex show a conspicuous dominance of terrestrial $n$-alkanes, and of terrestrial and microbial triterpenes. Their dominance evidences the primary terrigenous source of the organic matter, which is already established by $\delta^{13} \mathrm{C}$ and $\mathrm{C} / \mathrm{N}$ values of the same sediments (Stetten et al., 2015), and by their Rock-Eval characterization (Baudin et al., 2017 a, b). Rock-Eval results typified the organic matter as non mature Type III kerogen, sourced by terrestrial biomass and soils. The CPI values confirm that the lobe complex is a site of large accumulation of terrestrial organic carbon exported from the Congo catchment area to the deep ocean. The concentrations of terrestrial $n$ alkanes were in the same range as other marine coastal and marginal locations such as the Mediterranean Rhone and Ebro prodelta (Table 3), showing that the massive export of 
terrestrial organic matter through the Congo canyon results in similar terrestrial fingerprint as coastal shallow deposition sites, but in an abyssal location.

On top of this general homogeneous trend, terrestrial biomarker concentrations show some degree of variability (Figures 3 and 8 ), which will be discussed in the present section.

Site $B$ is located in the lobe 3 where a branch of the northern channel is only a few meter deep and is supposed to convey much less turbiditic inputs than the active southern channel ending at this site. Terrestrial $n$-alkane signatures at site $B$ and site $C$ are however comparable, revealing that $B$ receives the same organic matter as $C$, either from the northern channel or from overspilling of the turbidites going through the southern active channel.

At disconnected site $\mathrm{E}, \delta^{13} \mathrm{C}$ values show a dominance of marine organic matter (-22.8 to $24.2 \%$, Stetten et al., 2015). Phytadienes reflect the decay of recent algal remains in anaerobic conditions. Other phytoplanktonic fingerprints ( $n-C_{17}$ dominance) were not present. The lower accumulation rate $\left(0.1 \mathrm{~cm} \mathrm{yr}^{-1}\right)$ and the larger oxic layer $(6.6 \mathrm{~cm}$, Pozzato et al., this volume) than at the other studied sites involve a more extensive degradation at this site. The first centimetre of sediment has been accumulated during at least 20 years and the reported degradation rates of marine short-chain $n$-alkanes are coherent with their decay during this time period (Cheng et al., 2014; Grossi et al., 2002; Miralles et al., 2007). The sediment core collected at site $E$ has been deposited in less than a thousand years, while the corresponding channel ceased to fuel river particles to the lobe ca $4 \mathrm{kyr}$ ago (Rabouille et al., 2016). A striking characteristic of the upper $13 \mathrm{~cm}$ of the sediments at site $E$ is that its higher plant biomarker content compares well to that of sites $A, F$, or B, presently connected to the active canyon, despite the large difference in $\delta^{13} \mathrm{C}$ opposing the $\mathrm{E}$ site to the others (Figure S1, supplementary material). Given the hemipelagic source of the organic matter at $E$, a marked contribution of $n-C_{17}$, a planktonic alkane, would be expected, but is not found (Figure 2). A plausible explanation to this mismatch is the faster degradation of short-chain marine alkanes, relatively to more refractory terrestrial hydrocarbons. The molecular fingerprint (proportions in $n-C_{29}$, gammacerene and hop-17(21)-ene) of the terrestrial organic matter at site $\mathrm{E}$ reflects the same origin as at sites connected to the Congo canyon, and can be ascribed to Congo River inputs rather than from atmospheric aerosol deposition, 
the dominant source of terrestrial hydrocarbons at other open sea locations (Gogou et al, 2000). This is a striking evidence that significant river matter is admixed to the pelagic particles at site $E, 45 \mathrm{~km}$ away from the active channel. The deeper sedimentary horizons of site $\mathrm{E}$ showed an increase in several higher plant indicators, a feature also observed in the deeper horizon of the channel at site $C$. These signals seem to reveal an input of higher plant detritus in these horizons, in line with the slightly higher grain size and terrestrial phytoclasts (Stetten et al., 2015; Schnyder et al., this volume).

Pearson correlations of hydrocarbons concentrations normalized to organic carbons are shown in Table S2 (Supplementary material). They indicated that hydrocarbons with similar structures covaried, for instance, long-chain homologues on one hand, and short-chain homologues on the other, pointing to common source and comparable sensitivity to degradation (Table S2, Supplementary material). The Spearman correlations show that vascular plant $n$-alkanes covaried with some hopanes with $\alpha \beta\left(C_{20}\right)$ and $\beta \alpha\left(C_{30}\right)$ configuration, but vascular plant alkane concentrations showed no covariation neither with those of gammacerene nor fernene, biomarkers of ferns, nor with concentrations of oleanene and ursene, biomarkers of angiosperms. This suggests the occurrence of terrestrial remains from distinct types of vegetation. Palynofacies also showed variable relative abundances of amorphous organic matter (AmOM) and terrestrial phytoclasts (T-Phyt), however they did not allow to distinguish ferns and angiosperm remains (Schnyder et al., this volume). The denser T-Phyt were enriched in the channel of station A relatively to the less dense AmOM, whereas AmOM was enriched in the levee sediments at station $A$ and $C$, suggesting hydraulic sorting of the turbiditic particles. In the sediments enriched in AmOM, hydrocarbon concentrations are higher. It could be hypothesized that the lighter particles may be enriched in hydrocarbons. The enrichment in terrestrial alkanes in the deepest (19$22 \mathrm{~cm}$ ) horizons of the channel of station $\mathrm{C}$ and of station $\mathrm{E}$ corresponds to the highest T-Phyt palynomorphs and a more terrestrial organic matter as seen by $\delta^{13} \mathrm{C}$ values (Figure S1, supplementary material). It suggests either a physical sorting of particles within the same turbidite, or the occurrence of a second turbidite in the deepest layers, enriched in coarser terrestrial particles.

Interestingly, $\delta^{13} \mathrm{C}$ and $\mathrm{CPI}$, both classical indicators of higher plant contribution, showed no significant covariation in the present data set (Table S2, Supplementary material). $\delta^{13} \mathrm{C}$ did 
not covary significantly with any of the concentrations of aliphatic nor terpenoid terrestrial indicators. In the channel of site $\mathrm{C}, \delta^{13} \mathrm{C}$ of the organic matter is shifted towards more negative values, and the proportion of terrestrial phytoclasts in the palynofacies is higher. Both signals agree to indicate a higher fraction of non degraded terrestrial matter at this site.

Hydrocarbons are effectively degraded under oxic conditions. Experiments in coastal sediments have showed that alkanes having less than $25 \mathrm{C}$ atoms were degraded within one year. For example, between $29 \%$ and $84 \%$ of $n-C_{17}$ alkane was degraded in 500 days (Grossi et al., 2002; Miralles et al., 2007). The degradation of longer chain hydrocarbons is slower but also effective (80\% in one year, Grossi et al., 2002; 20 to $88 \%$ in 500 days, Miralles et al., 2007). The efficient mineralization of long-chain alkanols, another class of terrestrial lipids, was previously evidenced at a site located closer to the canyon head (Treignier et al., 2006). Diffusive oxygen uptake values showed that organic carbon was actively remineralized in the first centimeters of the Congo lobe sediments (Pozzato et al., this volume). The average sediment accumulation at site $C$ was exceptionally high, with a turbidite layer (of 10 to 20 $\mathrm{cm}$ ) being deposited every 2 to 3 years, while the sediment accumulation at $A$ and $F$ is one order of magnitude lower (Rabouille et al., 2016). Therefore the organic matter at stations $C$ remains in the oxic layer ca 10 times less than at $A$ and $F$. This shorter exposure to oxic degradation may result in less degraded terrestrial material at the distal site $C$ than at site $A$.

Phytadienes are produced by degradation of the phytyl side chain of chlorophylls during early diagenesis, while they are not produced during water column degradation processes (Grossi, 1996; Grossi et al., 1998). They have been shown to be readily degraded in aerobic sediments while low oxygen exposure favoured their preservation in cyanobacterial mats (Grossi, 1996; Pagès et al., 2014; Slowakiewicz et al., 2014). The spatial distribution pattern of phytadienes in the Congo lobe system contrasts with that of terrestrial $n$-alkanes and terpenoids (gammacerene, fernene, diploptene) by their absence in the river sediments and sediment traps and their marked enrichment at the site $C$ where they almost reach the concentrations of terrestrial $n$-alkanes. Phytadienes' occurrence confirms a greater input of labile chlorophylls, present in fresh plants or algae, to the sites $C$ and $B$, followed by their hydrolysis into phytadienes and the preservation of phytadienes under anaerobic conditions. The longer residence of turbidite particles in the oxic layer at sites $A$ and $F$ may have resulted in chlorophyll hydrolysis before they reached the anaerobic layer and explain the low 
abundance of phytadienes in these cores. Whereas hydrocarbons with similar structures (short-chain and long-chain alkanes, short-chain even hydrocarbons, hopenes, phytadienes), phytadienes and terpenoids of markedly difference structures, show significant covariation (Table S2). It evidences that phytadienes and terpenoids share a common source and shows that terpenoids are associated with recent inputs of terrestrial matter.

The bulk terrestrial signature at all sites is equivalent, but all aliphatic and terpenoid terrestrial hydrocarbons have higher concentrations at sites $C$ and $B$, normalized to organic carbon or to dry weight. The higher concentrations at site $\mathrm{C}$ could indicate that terrestrial hydrocarbons have been exposed to degradation for a shorter time within the sediments of site $C$ relatively to sites $A$ and $F$, and that terrestrial hydrocarbons decay faster than bulk terrestrial organic matter. According to its location at the end of an inactive channel, site B has a low sediment accumulation rate $\left(0.3 \mathrm{~cm} \mathrm{yr}^{-1}\right.$, Rabouille et al., 2016), comparable to that of site A. Therefore its hydrocarbon content was expected to be in the same range as that of site A. Surprisingly, concentrations of terrestrial $n$-alkanes, of terrestrial terpenes, and of phytadienes at site $B$ are similar to those of site $C$ and in turn, much higher than those of sites $A$ and $F$ (Figures 3, 5, 7, 8 and 9). Amongst the studies carried out by the COBGOLOBE consortium, only palynofacies characterization evidenced differences in the contribution of terrestrial organic matter pools between stations A and C, but station B was not considered (Schnyder et al., this volume). Bulk characteristics, like $\delta^{13} \mathrm{C}$ and $\mathrm{C} / \mathrm{N}$ did not differenciate sediments from sites A, F, B and C. The enrichment in phytadienes and terrestrial hydrocarbons indicates a larger fraction of recent terrestrial organic matter at sites $C$ and $B$, within an organic matter that is equally predominantly terrestrial at all sites A, F, C and B. Site B is located $10 \mathrm{~km}$ away from the active channel. In march 2001 sediment overspilling over the channel levees caused a significant flux of particles at site ZD, located $13 \mathrm{~km}$ off the channel (Khripounoff et al., 2003; Vangrieshem et al., 2009). The sedimentation rate recorded at site B (Rabouille et al., In this issue) is consistent with aggradation due to spillover from the feeding channel, and the less dense upper part of the turbidity currrents may reach site B (Dennieulou et al., this issue). Therefore the larger proportion of terrestrial hydrocarbons at site B may reflect deposition of labile terrestrial organic matter having recently overflown the levee. The morphology of the sediments at sites A and $F$ showed blocks and headscars (Dennielou et al., this issue) and indicate that sediments are eroded by 
sliding and levee dismantling. The lower proportion of phytadiene at sites A and $F$ may be linked to the erosion of recent turbiditic deposits at these sites.

4.2 Processes driving the hopene and triterpene spatial and temporal variabilities

The prevalence of hopanes and hopenes over steranes and sterenes indicates some contribution of microbiota as source of organic matter (Peters et al., 2005; Simoneit, 2005; Volkman et al., 1986; Volkman, 2005). The biological sources of the dominant triterpenes in the lobe sediments, hop-17(21)-ene, $\beta \beta$-hopane and diploptene (hop-22(29)-ene) are microorganisms and ferns (Douka et al., 2001; Innes et al., 1997, 1998; Pattituci et al., 1995; Rohmer et al., 1984; Rohmer, 1993; Rontani and Volkman 2005; Sinninghe-Damsté et al., 2014; Welander et al, 2010). They are dominant triterpenes in terrestrial environments with low maturity of the organic matter (Garel et al., 2014). Their predominance in the Congo River sediments suggests that the export of land particles to the lobe complex is a significant source of these triterpenes (Figure 6). The three river samples showed a larger abundance of the $C_{30}$ moretane ( $\alpha \beta$-hopane) than lobe sediments, suggesting that other inputs than river sediment contribute to hopenes in the lobe sediments.

Diploptene is a well-recognized terrestrial biomarker (Prahl et al., 1992) and gammacerene is a constituent of ciliates, ferns, purple non-sulfur bacteria and $\mathrm{N}$-fixing symbionts of plant roots (Bravo et al., 2001; Hamed al., 2014; Kleemann et al., 1990). Both are the only hydrocarbons covarying with the bulk terrestrial indicator $\delta^{13} \mathrm{C}$ (Table S2, Supplementary material), which shows that their spatial variability is related to the dominant fraction of terrestrial organic carbon. Both marine and terrestrial lineages of aerobic methane-oxidizing bacteria were characterized in the studied sediments (Bessette et al., 2017) and diploptene and gammacerene variations may reflect alive bacteria associated to soil and river organic matter.

Spearman correlations discriminate fern-8-ene, $\beta, \alpha$-hopane and hop-21-ene from the other terpenoids because in addition to covarying with other terpenoids, they also show significant covariance with terrestrial $n$-alkanes. Most terpenoids of Congo River sediments were transferred to the lobe sediments in similar relative proportions (Ts, hop-17(21)-ene, 
gammacerene, $\alpha \beta$ - and $\beta \beta$-hopane, $\beta \beta$ - $C_{31}$ homohopane). In contrast, hop-17(21)-ene and diploptene showed a variable contribution to total terpenoids (some sediments are devoid of diploptene), and both dominate at site C (Figure 6). Diploptene and hop-21-ene are constituents of anaerobic Geobacter and Zygomonas bacteria (Douka et al., 2001; Hartner et al., 2005), and the similarity in their vertical profiles favors the interpretation of a common anaerobic bacterial source for these isomers (Figure 9). Clay-catalyzed isomerisation of diploptene into hop-21-ene, further isomerisation into hop-17(21)-ene, and further degradation into neohop-13(18)-ene occur in immature sediments and may alter the precursor signature (Simoneit, 2005; Sinninghe-Damsté et al., 2014). The interplay between the soil contribution and the prediagenetic production of diploptene is illustrated by plotting the selected terpenoids concentrations versus that of gammacerene, synthesized by ciliates and bacteria, and generally considered as a terrestrial biomarker. In the present set of samples gammacerene covaries with $\delta^{13} \mathrm{C}$ and is therefore considered to stem from terrestrial bacteria or ciliates (Table S2, Supplementary material). The covariation of gammacerene with $\mathrm{C}_{27}$ 18(H)-22,29,30-trisnorhopane (Ts) shown in the cross plot of their concentrations is consistent with a same continental source of both compounds (Figure 10). In contrast, the scatter in the plots of neohop-13(18)-ene and hop-17(21)-ene versus gammacerene suggests additional contributions of organic matter than those from terrestrial origin (Figure 10). The plot of diplotene versus gammacerene concentrations shows some degree of scatter but still with a clear covariance, suggesting the existence of a mixture of terrestrial organic matter inputs with other inputs of organic matter, more likely a contribution from marine bacteria added to terrestrial soil microorganisms .

Diploptene and its $\Delta 21$ isomer show identical subsurface peaks in subsurface sediments at site $\mathrm{E}$ (Figure 9). In the upper sediment layers of site $\mathrm{E}$, palynofacies and $\delta^{13} \mathrm{C}$ values indicate low proportion of higher plant remains and bacteria may be major contributors to these hopenes. Almost identical vertical profiles of hop-17(21)ene and neohop-13(18)-ene at sites $\mathrm{C}$ and $\mathrm{E}$ suggest either common precursor organisms or sequential isomerisation of hop-21ene into hop-17(21)ene and further transformation into neohop-13(18)-ene (Figure 11). Similar correlations were observed in a more mature terrestrial set of samples (Garel et al., 2014). In a large set of immature marine and lacustrine samples, matching $\delta^{13} \mathrm{C}$ values of both compounds evidenced a diagenetic relationship or a common source in (Sinninghe- 
Damsté et al., 2014). The series of neohop-13(18)-enes identified in a range of recent and ancient sediments included $C_{27}$ to $C_{30}$ homologues. In the Congo lobe sediments, the series was limited to the $C_{30}$ and $C_{27}$ neohop-13(18)-enes, and corresponds to the composition of recent sediments from other locations (Sinninghe-Damsté et al., 2014).

\subsection{Petroleum contamination}

The occurrence of oil hydrocarbons (UCM, $C_{23}$ and $C_{24}$ tricyclic triterpanes) indicate a notable petroleum contamination of the first surface centimetre of the sediment at site $E$, but absent underneath (Table S1, supplementary material). Below the contaminated layers, the CPI is consistent with a higher plant source of the high molecular weight alkanes, alike at the other studied sites. Oil hydrocarbons are also evidenced in lower concentrations at site A and C. In all contaminated sediments, ratio values of UCM / resolved hydrocarbons indicate non degraded oil. A strong petroleum odour was noted when slicing the top of contaminated cores (site $\mathrm{E}$, site $\mathrm{C}$ ) and the proportion of UCM to aliphatic hydrocarbons evidenced that the petroleum was non degraded (Burns et al., 2010). UCM and alkanes concentrations remained on the same order of magnitude as moderately contaminated coastal sites (Bouloubassi et al., 2001; Tolosa et al., 1996) and are at least one order of magnitude less abundant than in heavily contaminated coastal areas such as Alexandria harbor and the Rhine estuary (Aboul-Kassim and Simoneit, 1995; Stronkhorst and van Hattum, 2003). UCM covariates with short-chain alkanes in the range $C_{15}-C_{18}$, with pristane, phytane, and $C_{23}$ and $\mathrm{C}_{24}$ tricyclic diterpanes, suggesting a fossil source for these compounds (Table S2, supplementary material). Another molecular evidence for petroleum occurrence is the series of tricyclic diterpanes from $\mathrm{C}_{21}$ to $\mathrm{C}_{26}$ dominating over other terpanes and terpenes on the $\mathrm{m} / \mathrm{z}=191$ fragmentogram of the surficial sediment of site $E$ and absent in non-contaminated location nearby (Figure S3, supplementary material).

The origin of this crude oil contamination is difficult to assert with certainty. The background oil occurrence characterized in sediments along the end of the canyon may come from soil particles from Kinshasa, from hydrocarbon accidental release from Matadi and Boma harbours and from the Banana oil terminal. Crude oil is extracted from the offshore blocks located close to the coast on the Northern side of the canyon (Congo-brazzaville- 
hydrocarbons-blocks, 2017) and the possibility that accidental oil spills may have reached the lobe area cannot be ruled out.

The striking enrichment in short chain alkanes with an even predominance at the levee of site $C$ are difficult to explain. These compounds are unusual in marine systems, and are consistent with several sources of organic matter. They were first characterized in evaporitic environments in which the highly reducing conditions favor reduction of fatty acids rather than their $\beta$-decarboxylation (Moldowan et al., 1985; Zhang and Paul, 2012). They were also observed in oxygenated environments and were interpreted as a direct microbiota inputs generated by $\beta$-decarboxylation of bacterial odd fatty acids (Grimalt and Albaigés, 1987; Nishimura and Baker, 1986). The predominance of $C_{18}$ in lacustrine sediments was considered to be inherited from planktonic and/or bacterial cells (Affouri and Sahraoui, 2017). A short chain mode of even alkanes was observed in C3 trees and C4 grasses, woodland and grassland soils (Table 2). It was also identified in charred biomass and in soils with a coal fraction, however maximizing at $C_{16}$ and $C_{18}$ (Eckmeier and Wiesenberg, 2009). Finally, $\Delta^{14} \mathrm{C}$ values of hydrocarbons from sediments from the China East margin Sea showed that $\mathrm{C}_{16}$ and $\mathrm{C}_{18}$ had a fossil origin (Tao et al., 2016). In the sedimentary context of Congo lobe complex, this signature is consistent with a higher plant, a bacterial signature and a fossil contribution. It is present in most of the samples from the lobe system, in the river sediments and even in some sediment trap samples. However the fainter $C_{16}$ and $C_{18}$ fingerprint in the river sediment samples argues for another origin than higher plants (Figure 4). $C_{14}, C_{16}$ and $C_{18}$-alkanes were correlated to the chromatographically unresolved hydrocarbons (Unresolved Compound Mixture, UCM) (Table S2, Supplementary material). However, these alkanes were more abundant than their odd counterparts in many samples where UCM cannot be quantified. The last likely sources expected to yield a broad repartition of short-chain alkanes are soil bacteria, shown to contribute to alive microbial communities of aerobic methane-oxidizing bacteria (Bessette et al., 2017). The degradation products of diploptene, hop-21-ene and neoho-13(18)-ene also displayed their highest concentrations at the levee of site $C$ (Figures 4 and 11). The occurrence of this group of hopenes in bacteria (Table 3) evokes a possible bacterial source for both groups of hydrocarbons. ${ }^{14} \mathrm{C}$ isotopic ratios of alkanes would unequivocally ascribe the source of even short-chain alkanes but they were not available in the present study. 


\subsection{Dynamics of terrestrial organic matter inputs}

Fluxes of alkanes are seldom reported, and the highest values of terrestrial alkanes are measured in subtropical shelf (Sikes et al., 2009). The accumulation fluxes of terrestrial alkanes measured in the Congo terminal lobe are in the upper range of previous measurements in deep marine environments (Table 3). Terrestrial $n$-alkanes and triterpenes fingerprint two different sources of terrestrial organic matter, as shown by the Pearson correlation of $\delta^{13} \mathrm{C}$ to gammacerene and diploptene, and not to odd $n$-alkanes in the range $\mathrm{C}_{25}-\mathrm{C}_{37}$ (Table S2, Supplementary material). However the dynamics of both terrestrial components in the terminal lobe sediments is equally driven by the accumulation of particles fuelled by the canyon. This overwhelming lateral input of particles masks the contribution of atmospheric deposition, which generally dominates abyssal fluxes of terrestrial $n$-alkanes in the open ocean. The concentration gradient of terrestrial $n-C_{29}$ and gammacerene at the different sites (Sites $\mathrm{C}$ and $\mathrm{B}>$ Site $\mathrm{B}>$ Site $\mathrm{E}$ ) combine with the mass accumulation rates (Site $C>$ Site $A$ abd $B>$ Site $E$ ) to yield a decreasing magnitude of accumulation fluxes from site $C$, sites $A$ and $B$, and the disconnected site $E$ (Figure 12 ).

One-year time series of sediment trap sampling in the lobe complex and at sites located upstream showed a typical pelagic flux for most of the year (Khripounoff, personal communication) with 2 peaks of particles at the site located upstream in the channel (Regab $Z^{\prime}, \operatorname{Tr}$ C1 February 2011, Tr C4 from the $29^{\text {th }}$ of March to the $13^{\text {th }}$ of April 2011). Mass flux peak at $\operatorname{Tr} \mathrm{C} 1$ and $\operatorname{Tr}$ C4 showed likely erosion of the flanks or of the levees of the channel (124 and $877 \mathrm{~g} \mathrm{~m}^{-2} \mathrm{yr}^{-1}$ ). Except for these events, mass flux was within a range consistent with pelagic sinking fluxes of particles $\left(25-49 \mathrm{~g} \mathrm{~m}^{-2} \mathrm{yr}^{-1}\right)$. The sinking particles were enriched in the planktonic $n-C_{17}$ in relation to others alkanes (Figure S2, Supplementary Material). The sedimentation of particles $40 \mathrm{~m}$ above the sediment fuels about one tenth of the terrestrial $n$-alkanes flux accumulated in the sediments at site C (Figure 12). It clearly shows that the vertical rain of particles contributes a minor fraction of the organic matter preserved in the sediments at site $C$, and that the sediment is controlled by lateral transport of particles through the canyon (Figure 12). When the canyon flanks and levees are destabilized, a massive input of particle is captured by the sediment trap ( $\operatorname{Tr}(4)$, yielding unusually high 
sedimentation of terrestrial alkanes, reaching the high alkane sedimentary accumulation rates at $C$. At sites $A, B$ and $E$ the similar order of magnitude of sediment accumulation rates in one hand, and of vertical flux supported by sinking particles on the other, evidences that river inputs are not preserved into these sediments, either they are degraded by the microorganisms or they are further transported towards site $C$. Eventhough site B, receiving overspilling particles from the active channel, shows a similar proportion of labile hydrocarbons sourced by higher plant debris as site $C$ sediments, their sedimentary accumulation rates at $B$ show that these inputs are little significant in terms of fluxes.

\section{Conclusions}

Hydrocarbons of the Congo lobe complex have a marked higher plant fingerprint, in agreement with the bulk geochemical characteristics showing the dominance of terrestrial matter. Terrestrial biomarkers from higher plants, ferns and bacteria and angiosperms show ample variations in their contributions, indicating heterogeneous sources of the soil and vegetation detritus delivered to the sediments of the terminal lobe system at the end of the Congo submarine canyon. Hydrocarbon composition variations may reflect both different sources of the organic matter and different exposure to degradation, implied by the two-fold difference in mass accumulation rates of sediments of the terminal lobe complex.

At the more distal site $C$, the sediment accumulation is higher and the sediments spend less time in the oxic layer than at other sites. These sediments displayed higher organic carbonnormalized concentrations of terrestrial hydrocarbons than those where the exposure to oxic degradation is longer, suggesting that bulk organic carbon degrades faster than terrestrial hydrocarbons in the first steps of the pre-diagenesis. Despite their much smaller concentrations, terrestrial hydrocarbons and terrestrial terpenes are still present at the site disconnected from the active channel (site E) bringing evidences for the admixture of some river particles to the planktonic organic matter, dominant at this site.

The occurrence of a minor terrestrial signal in the sediment traps shows that some sediment from the levees may be destabilized, and form nepheloid layers that are admixted to the vertical flux of pelagic sinking particles. Corresponding vertical flux may produce pulses of 
terrestrial hydrocarbons but the general vertical fluxes of terrestrial hydrocarbons are one order of magnitude lower than hydrocarbon accumulation fluxes in the sediment at site $\mathrm{C}$. It evidences the magnitude of the inputs delivered by turbidites through the active channel and clearly demonstrate that lateral transport controls the supply of organic matter to the terminal lobe complex.

\section{Acknowledgments:}

We are indebted to the captains and crews of the N.O. Pourquoi Pas ? who operated the ship and her equipment during WACS and Congolobe cruises, and to K. Olu and C. Rabouille who were the Chief scientists for the WACS and Congolobe cruises respectively. We acknowledge B. Bombled and P. Noel for operating the multicore on board. G. Vetion and S. Bourgeois conditioned the samples onboard, and C. Senyarich and E. Stetten weighted and lyophilised them back at the laboratory. We thank Rob Spencer and Helen Talbot who shared their samples from the Congo River. This research was funded by ANR Congolobe (ANR Blanc 601 SIMI5-6, n¹1 BS56 030) and IFREMER (Project "Biodiversité et dynamique des écosystèmes profonds, impacts"). We thank the PI of Congolobe, Christophe Rabouille, for stimulating exchange of data and ideas though regular meetings.

We would like to thank two anonymous reviewers for their valuable comments and helpful suggestions on an earlier version of the manuscript.

\section{References}

Aboul-Kassim, T. A. T., Simoneit, B. R. T., 1995. Aliphatic and Aromatic Hydrocarbons in Particulate Fallout of Alexandria, Egypt: Sources and Implications. Environmental Science and Technology, 29: 2473-2483.

Affouri, H., Sahraoui, O., 2017. The sedimentary organic matter from a Lake Ichkeul core (far northern Tunisia): Rock-Eval and biomarker approach. Journal of African Earth Sciences 129: 248-259. http://dx.doi.org/10.1016/j.jafrearsci.2017.01.017

Ageta, H., Arai, Y., 1983. Fern constituents: Pentacyclic triterpenoids isolated from Polypodium niponicum and P. formosanum. Phytochemistry, 22: 1801-1808.

Banta, A. B, Wei, J. H, Welander, P. V., 2015. A distinct pathway for tetrahymanol synthesis in bacteria. Proc. Natl. Acad. Sci., 112(44): 13478-13483. doi: 10.1073/pnas.1511482112.

Baudin, F., Disnar, J .R., Martinez, P., Dennielou, B., 2010. Distribution of the organic matter in the channel-levees systems of the Congo mud-rich deep sea fan (West Africa). Implication for deep offshore petroleum source rocks and global carbon cycle. Mar. Petrol. Geol. 27, 995-1010. 
Baudin, F., Stetten, E., Schnyder, J., Charlier, K., Martinez, P., Dennielou, B., Droz, L., 2017. Origin and distribution of the organic matter in the distal lobe of the Congo deep-sea fan - A Rock-Eval survey. Deep Sea Res. Part II (in press). doi: 10.1016/j.dsr2.2017.01.008

Baudin F., Martinez, P., Dennielou, B., Charlier, K., Marsset, T., Droz, L., Rabouille, C., 2017. Organic carbon accumulation in modern sediments of the Angola basin influenced by the Congo deep sea fan. Deep Sea Res. Part II (in press). doi: 10.1016/j.dsr2.2017.01.009.

Bessette, S., Moalic, Y. Gautey, S., Lesongeur, F., Godfroy, A., Toffin, L., 2017. Relative Abundance and diversity of bacterial methanotrophs at the oxic-anoxic interface of the Congo deep-sea fan. Frontiers in Microbiology, 8:715. doi: 10.3389/fmicb.2017.00715.

Blair, N. E., Aller R. C., 2012. The fate of terrestrial organic carbon in the marine environment. Annual Review of Marine Science, 4: 401-423.

Bonnel, C., 2005. Mise en place des lobes distaux dans les systèmes turbiditiques actuels : Analyse comparée des systèmes du Zaïre, Var et Rhône. Thèse de doctorat, Université de Bordeaux I, 275 p.

Bouloubassi, I., Fillaux, J. Saliot, A., 2001. Hydrocarbons in surface sediments from the changjiang (Yangtze River) estuary, East China Sea. Mar. Pollut. Bull. 42, 1335-1346.

Burdige, D. J., 2005. Burial of terrestrial organic matter in marine sediments: A reassessment, Global Biogeochem. Cycles, 19, GB4011, doi:10.1029/2004GB002368.

Burdige, D. J., 2007. Preservation of Organic Matter in Marine Sediments: Controls, Mechanisms, and an Imbalance in Sediment Organic Carbon Budgets? Chemical Review, 107: 467-485.

Burns, K. A., Brinkman, D. L., Brunskill, G. J., Logan, G. A., Volk, H., Wasmund, K., Zagorskis, I., 2010. Fluxes and fate of petroleum hydrocarbons in the Timor Sea ecosystem with special reference to active natural hydrocarbon seepage. Marine Chemistry, 118, pp 140-155.

Brassell, S. C., Eglinton, G., 1983. Steroids and triterpenoids in deep sea sediments as environmental and diagenetic indicators. In: Bjorøy, M. et al. (Eds.), Advances in Organic Geochemistry, 1981. J. Wiley and Sons, New York, pp. 684-697.

Brassell, S. C., 1984. Aliphatic Hydrocarbons of a Cretaceous Black Shale and Its Adjacent Green Claystone From the Southern Angola Basin, Deep Sea Drilling Project Leg 75. 33: 1019-1029, doi:10.2973/dsdp.proc.75.133.1984.

Bravo, J.-M., Perlz, M., Hartner, T., Kannenberg E. L., Rohmer, M. 2001. Novel methylated triterpenoids of the gammacerane series from the nitrogen-fixing bacterium Bradyrhizobium japonicum USDA 110. Eur. J. Biochem., 268: 1323-1331. DOI: 10.1046/j.1432-1327.2001.01998.x 
Broman, D., Colmsjö, A., Ganning, B., Näf, C., Zebühr, Y., and Östman, C., 1987. Fingerprinting petroleum hydrocarbons in bottom sediment, plankton, and sediment trap collected seston. Marine Pollution Bulletin 18, pp. 380-388.

Cathalot, C., Rabouille, C., Tisnerat-Laborde, N., Toussaint, F., Kerhervé, P., Buscail, R., Loftis, K., Sun M. -Y., Tronczynski, J., Azoury, S., Lansard, B., Treignier, C., Pastor L., Tesi, T., 2013. The fate of river organic carbon in coastal areas: A study in the Rhone River delta using multiple isotopic (delta C-13, Delta C-14) and organic tracers. Geochimica et Cosmochimica Acta, 118: 33-55. http://doi.org/10.1016/j.gca.2013.05.001.

Cartapanis, O., Bianchi, $\quad$ D., Jaccard, S. L. ， Galbraith, E. D., 2016. Global pulses of organic carbon burial in deep-sea sediments during glacial maxima. Nature Communications, 7: Article number: 10796. doi:10.1038/ncomms10796

Castañeda, I. S., Werne, J. P. , Johnson T. C., Powers, L. A., 2011. Organic geochemical records from Lake Malawi (East Africa) of the last 700 years, part II: Biomarker. Palaeogeography, Palaeoclimatology, Palaeoecology, 303 :140-154.

Cheng, L., Shi, S., Li, Q., Chen, J., Zhang, H., Lu, Y., 2014. Progressive Degradation of Crude Oil n-Alkanes Coupled to Methane Production under Mesophilic and Thermophilic Conditions. PLoS ONE 9(11): e113253. doi:10.1371/journal.pone.0113253.

Clark, R.C., Blumer, M., 1967. Distribution of $n$-paraffins in marine organisms and sediment. Limnology and Oceanography, 12: 79-87.

Congo-brazzaville-hydrocarbons-blocks: (c) Copyright 2017 The Oil \& Gas Year Limited. The Oil and Gas Year; [accessed 2017 May 03]. http://shop.theoilandgasyear.com/congo-brazzavillehydrocarbons-blocks/.

Coynel, A., Seyler, P., Etcheber, H., Meybeck, M., Orange D., 2005. Spatial and seasonal dynamics of total suspended sediment and organic carbon species in the Congo River. Global Biogeochem. Cycles 19, GB4019. doi:10.1029/2004GB002335.

Dennielou, B., Droz, L., Jacq, C., Bonnel, C., Babonneau, N., Picot, M., Le Saout, M., Saout, Y., Bez, M., Savoye, B., Olu, K., Rabouille, C., submitted. Morphology, structure, composition and build-up processes of the Congo channel-mouth lobe complex. This volume.

Douka, E., Koukkou, A. I., Drainas, C., Grosdemange-Billiard, C., Rohmer, M., 2001. Structural diversity of the triterpenic hydrocarbons from the bacterium Zymomonas mobilis: the signature of defective squalene cyclization by the squalene/hopene cyclase. FEMS Microbiology Letters, 199: 247-251.

Eckmeier, E., Wiesenberg, G. L. B., 2009. Short-chain $n$-alkanes (C16-20) in ancient soil are useful molecular markers for prehistoric biomass burning. Journal of Archaeological Science 36(7): 1590-1596. DOI: 10.1016/j.jas.2009.03.021. 
Eglinton, G., Hamilton, R. J., Raphael, R. A., Gonzalez, A. G., 1962. Hydrocarbon Constituents of the Wax Coatings of Plant Leaves: A Taxonomic Survey, 1962. Nature 193(2):739-742 . DOI: $10.1038 / 193739 a 0$.

Eglinton, G., Hamilton, R. J., 1967. Leaf epicuticular waxes. Science, 156 :1322-1335.

Garel, S., Quesnel, F., Jacob, J., Roche, E., Le Milbeau, C., Dupuis, C., Boussafir, M., Baudin, F., Schnyder, J., 2014. High frequency floral changes at the Paleocene-Eocene Boundary revealed by comparative biomarker and palynological studies. Organic Geochemistry, 77: 43-58. DOI:10.1016/j.orggeochem.2014.09.005.

Gogou, A., Bouloubassi, I., Stephanou, E. G., 2000. Marine organic geochemistry of the Eastern Mediterranean: 1. Aliphatic and polyaromatic hydrocarbons in Cretan Sea surficial sediments. Mar. Chem., $68: 265-282$

Gordon, E. S.; Goñi, M. A., 2004. Controls on the distribution and accumulation of terrigenous organic matter in sediments from the Mississippi and Atchafalaya river margin. Marine Chemistry, $92: 331-332$.

Grimalt, J. O., Albaigés, J., 1987. Sources and occurrence of C12-C22 n-alkane distributions with even carbon-number preference in sedimentary environments. Geochimica Cosmochimica Acta, 51:1379-1384.

Grossi V., 1996. Formation et devenir des phytadiènes dans le milieu marin: implication de ces hydrocarbures dans les processus de dégradation des chlorophylles à chaîne phytyle. Origin and fate of phytadienes in the marine environment: implication of these hydrocarbons in degradation processes of chlorophylls with a phytyl side chain. PhD Universite d'Aix-Marseille 2, Marseille, France. 189p.

Grossi, V., Hirschler, A., Raphel, D., Rontani, J.-F., De Leeuw, J. W., Bertrand, J.-C., 1998. Biotransformation pathways of phytol in recent anoxic sediments. Organic Geochemistry, 29: 845-861.

Grossi, V., Massias, D., Stora, G., Bertrand, J.-C., 2002. Burial, exportation and degradation of acyclic petroleum hydrocarbons following a simulated oil spill in bioturbated Mediterranean coastal sediments. Chemosphere, 48 : 947-954.

Hamed, A. I, Masollo, M., Peciso, L., Gallotta, D., Mahalel, U. A., Pawelec, S., Stochmal, A., Piacente, S., 2014. Unusual Fernane and Gammacerane Glycosides from the Aerial Parts of Spergula fallax. Journal of Natural Products, 77: 657-662.

Häggi, C., Sawakuchi, A. O., Cristiano, C. M.; Mulitza, S., Mollenhauer, G., Sawakuchi, H. O., Baker, P. A., Zabel, M., Schefuß, E., 2016. Origin, transport and deposition of leaf-wax biomarkers in the Amazon Basin and the adjacent Atlantic. Geochimica et Cosmochimica Acta, 192: 149-165

Härtner, T., Shraub, K. L., Kannenberg, E., 2005. Occurrence of hopanoid lipids in anaerobic Geobacter species. FEMS Microbiology Letters, 243: 59-64. doi:10.1016/j.femsle.2004.11.039. 
Hemingway, J. D., Schefuß, E.; Dinga, B. J., Pryer, H., Galy, V. V., 2016. Multiple plant-wax compounds record differential sources and ecosystem structure in large river catchments. Geochimica et Cosmochimica Acta, 184: 20-40. doi:10.1016/j.gca.2016.04.003.

Herrmann, N., Boom, A., Carr, A. S., Chase, B. M., Granger, R., Hahn A., Zabel, M., Schefuß , E., 2016. Sources, transport and deposition of terrestrial organic material: A case study from southwestern Africa. Quaternary Science Reviews 149: 215-229. http://dx.doi.org/10.1016/j.quascirev.2016.07.028.

Innes, H. E., Bishop, A. N., Head, I. M., Farrimond, P., 1997. Preservation and diagenesis of hopanoids in Recent lacustrine sediments of Priest Pot, England. Organic Geochemistry, 26: 565-576.

Innes, H. E., Bishop, A. N., Fox, P. A., Head, I. M., Farrimond, P., 1998. Early diagenesis of bacteriohopanoids in Recent sediments of Lake Pollen, Norway. Organic Geochemistry, 29:1285-1295.

Khripounoff A., Vangriesheim A., Babonneau N., Crassous P., Dennielou B. and B. Savoye, 2003. Direct observation of intense turbidity current activity in the Zaire submarine valley at $4000 \mathrm{~m}$ water depth. Marine Geology, 194(3-4): 151-158. http://doi.org/10.1016/S0025-3227(02)00677-1.

Kim, J.H., Zell, C., Moreira-Turcq, P., Pérez, M. A. P., Abril G., Mortillaro, J.-M., Weijers J. W. H., Meziane, T., Sinninghe Damsté, J. S, 2012. Tracing soil organic carbon in the lower Amazon River and its tributaries using GDGT distributions and bulk organic matter properties. Geochimica et Cosmochimica Acta, 90 : 163-180.

Kleemann, G., Poralla, K., Englert, G., Kjösen, H., Liaaen-Jensen, S., Neunlist, S., Rohmer, M. , 1990. Tetrahymanol from the phototrophic bacterium Rhodopseudomonas palustris: first report of a gammacerane triterpene from a prokaryote. J. Gen. Microbiol. 136, 2551-2553.

Kuhn, T. K., Krull, E. S., Bowater, A., Grice, K., Gleixner, G., 2010. The occurrence of short chain $n$-alkanes with an even over odd predominance in higher plants and soils. Organic Geochemistry, 41 (2): 88-95. DOI http://dx.doi.org/10.1016/j.orggeochem.2009.08.003

1. Kvenvolden, K.A., Hostettler, F. D., Franck, T. J., 1990. Hydrocarbons in sediments of the Weddell Sea, Antarctica. Proceedings of the Ocean Drilling Program, 113: 199-208.

2. Lopes dos Santos, R. A., Vane, C. H., 2016. Signatures of tetraether lipids reveal anthropogenic overprinting of natural organic matter in sediments of the Thames Estuary, UK. Organic Geochemistry, 93: 68-76. http://dx.doi.org/10.1016/j.orggeochem.2016.01.003.

Liu, L.-Y., Wang, J.-Z., Guan, Y.-F., Zeng, E. Y., 2013. Use of aliphatic hydrocarbons to infer terrestrial organic matter in coastal marine sediments off China. Marine Pollution Bulletin 64 (2012) 1940-1946. http://dx.doi.org/10.1016/j.marpolbul.2012.04.023. 
Maciel, D. C., Botelho de Souza, J. R., Taniguchi, S., Bícegoc, M. C., França Schettini, C. A., Zanardi-Lamardo, E., 2016. Hydrocarbons in sediments along a tropical estuary-shelf transition area: Sources and spatial distribution. Marine Pollution Bulletin 113: 566-571.

Mangelsdorf, K., Güntner, U., Rullkötter, J., 2000. Climatic and oceanographic variations on the California continental margin during the last 160 kyr. Organic Geochemistry, 31: 829-846.

3. Marty, J.-C., Nicolas, E., Miquel, J.-C., Fowler, S. W., 1994. Particulate fluxes of organic compounds and their relationship to zooplankton fecal pellets in the northwestern Mediterranean Sea. Marine Chemistry 46: 387-405.

Marynowski, L., Zaton, M., Simoneit B. R. T., Otto, A., Jedrysek, M. O., Grelowski, C., Kurkiewicz, S., 2007a. Compositions, sources and depositional environments of organic matter from the Middle Jurassic clays of Poland. Applied Geochemistry, 22: 2456-2485.

Marynowski, L., Otto, A., Zaton, M., Philippe, M., Simoneit, B.R.T., 2007b. Biomolecules preserved in ca. 186 million year old fossil conifer wood. Naturwissenchaften, 94: 228-236.

Middelburg, J., Vlug T., Jaco, F., van der Nat., W.A., 1993. Global and Planetary Change, 8: 47-58.

4. Miralles, G., Grossi, V., Acquaviva, M., Duran, R., Bertrand, J.-C., Cuny, P., 2007. Alkane biodegradation and dynamics of phylogenetic subgroups of sulfate-reducing bacteria in an anoxic coastal marine sediment artificially contaminated with oil. Chemosphere, 68: 1327-1334. doi:10.1016/j.chemosphere.2007.01.033.

Moldowan, J.M., Seifert, W.K., Gallegos, E.J., 1985. Relationship between petroleum composition and depositional environment of petroleum source rocks. American Association of Petroleum Geologists Bulletin, 69: 1255-1268.

Nishimura, M., Baker E. W., 1986. Possible origin of $n$-alkanes with a remarkable even-to-odd predominance in recent marine sediments. Geochimica Cosmochimica Acta, 50 : 299305.

Olu K., 2011. WACS cruise, Pourquoi Pas? R/V, http://dx.doi.org/10.17600/11030010 .

5. Pagès, A., Grice, K., Vacher, M., Welsh D. T., Teasdale, P. R, Bennett, W. W., Greenwood, P., 2014. Characterizing microbial communities and processes in a modern stromatolite (Shark Bay) using lipid biomarkers and two-dimensional distributions of porewater solutes. Environmental Microbiology, 16 (8): 2458-2474. DOI: 10.1111/1462-2920.12378.

Paull, R., Michaelsen, B.H., McKirdy, D.M., 1998. Fernenes and other triterpenoid hydrocarbons in Dicroidium-bearing Triassic mudstones and coals from South Australia. Organic Geochemistry, 29: 1331-1343.

Patitucci, M. L., Pinto, A. C., Cardoso, T. N., 1995. Analysis of crude extracts and fractions of Brazilian Polypodiaceae by high resolution gas chromatography mass- 
spectrometry. I. Triterpenes. Phytochemical Analysis, 6: 38-44.

http://dx.doi.org/10.1002/pca.2800060106.

6. Peters, K., Walters, C., Moldowan, M., 2005. The biomarker Guide. Biomarkers and Isotopes in the Petroleum Exploration and Earth History, vol. 2, second ed. Cambridge University Press, Cambridge.

Pozzato, L., Cathalot, C., Berrached, C., Toussaint, F., Stetten, E.; Caprais, J.-C.; Pastor, L.; OluLeroy, K.; Rabouille, C., under revision. Early diagenesis in the Congo deep-sea fan sediments dominated by massive terrigenous deposits: Part I - Oxygen consumption and organic carbon mineralization using a micro-electrode approach. This volume.

Prahl, F. G., Hayes, J. M., Xie, T.-M., 1992. Diploptene: an indicator of terrigeneous organic carbon in Washington coastal sediments. Limnology and Oceanography, 37: 1290-1300.

7. Qin, B., Liu, Z., Havens, K., 1997. Eutrophication of Shallow Lakes with Special Reference to Lake Taihu, China. Hydrobiologia 581 :89-95. DOI 10.1007/s10750.006 0510-8.

Rabouille, C., Caprais, J.-C., Lansard, B., Crassous, P., Dedieu, K., Reyss, J.-L., Khripounoff, A., 2009. Organic matter budget in the Southeast Atlantic continental margin close to the Congo Canyon: In situ measurements of sediment oxygen consumption. Deep-Sea Res. Part II, 56: 2223-2238.

Rabouille, C., Olu, K., Baudin, F., Khripounoff, A., Dennielou, B., Arnaud-Haond, S., Babonneau, N., Bayle, C., Beckler, J., Bessette, S., Bombled, B., Bourgeois, S., Brandily, C., Caprais, J.-C., Cathalot, C., Charlier K., Corvaisier, R., Croguennec, C., Cruaud, P., Decker, C., Droz, L., Gayet, N., Godfroy, A., Hourdez, S., Le Bruchec, J., Le Saout, J., Lesaout, M., Lesongeur, F., Martinez, P., Mejanelle, L., Michalopoulos, P., Mouchel, O., Noel, P., Pastor, L., Picot, M., Pignet, P., Pozzato, L., Pruski, A.M., Rabiller, M., Raimonet, M., Ragueneau, O., Reyss, J.-L., Rodier, P., Ruesch, B., Ruffine, L., Savignac, F., Senyarich, C., Schnyder, J., Sen, A., Stetten, E., Sun, M-Y., Taillefert, M., Teixeira, S., TisneratLaborde, N., Toffin, L., Tourolle, J., Toussaint, F., Vetion, G., Jouanneau, JM., Bez, M., 2016. The Congolobe project, a multidisciplinary study of Congo deep-sea fan lobe complex: Overview of methods, strategies, observations and sampling. Deep-Sea Res. Part II. DOI: 10.1016/j.dsr2.2016.05.006

Rezende, C.E., Pfeiffer, W.C. , Martinelli, L.A., Tsamakis, E., Hedges, J.I., Keil, R.G., 2010. Lignin phenols used to infer organic matter sources to Sepetiba Bay - RJ, Brasil. Estuarine, Coastal and Shelf Science, $87: 479-486$

Rohmer, M., 1993. The biosynthesis of triterpenoids of the hopane series in the eubacteria a mine of new enzyme reactions. Pure and Applied Chemistry 65: 1293-1298.

Rohmer, M. P., Bouvier-Nave, P., Ourisson, G., 1984. Distribution of hopanoid triterpenes in prokaryotes. J. Gen. Microbiol. 130: 1137-1150.

Rommerskirchen, F., Plader, A., Eglinton, G., Chikaraishi, Y., Rullkötter, R., 2006. Chemotaxonomic significance of distribution and stable carbon isotopic 
composition of long-chain alkanes and alkan-1-ols in C4 grass waxes. Organic Geochemistry 37: 1303-1332.

Rontani, J.-F., Volkman, J.K., 2005. Lipid characterization of coastal hypersaline cyanobacterial mats from the Camargue (France). Organic Geochemistry 36: 251-272.

Romero-Viana, L., Ulrike, K., Sachse, D., 2012. Lipid biomarker signatures in a hypersaline lake on Isabel Island (Eastern Pacific) as a proxy for past rainfall anomaly (1942-2006 AD). Palaeogeogr. Palaeoclimatol. Palaeoecol. , doi:10.1016/j.palaeo.2012.06.011.

8. Savoye, B., Denniellou, B., Babonneau, N., Bez, M., 2009.Geological overview of the AngolaCongo Margin, the Congo deep-sea fan and its submarine valleys. Deep-Sea Research II, 56: 2169-2182.

9. Schefuß,E., Versteegh, G. J. M., Jansen, J. H. F., Sinninghe Damsté, J. S., 2004. Lipid biomarkers as major source and preservation indicators in SE Atlantic surface sediments. Deep-Sea Research I 51: 1199-1228.

Shiojima, K., Ageta, H., 1990. Fern Constituents: Two New Triterpenoid Hydrocarbons, Hop16-ene and isohop-22(29)-ene, Isolated from Davallia mariesii. Chemical and Pharmaceutical Bulletin 38, 347-349.

Sikes, E., Uhle, M. E., Nodde, S. D.,. Howard, M. E., 2009. Sources of organic matter in a coastal marine environment: Evidence from $n$-alkanes and their $\delta^{13} \mathrm{C}$ distributions in the Hauraki Gulf, New Zealand. Marine Chemistry, 113: 149-163. doi:10.1016/j.marchem.2008.12.003

Simoneit, B. R. T., 2005. A review of current applications of mass spectrometry for biomarker/molecular tracer elucidations. Mass Spectrometry Reviews, 2005, 24, 719765.

Sinninghe-Damsté, J. S., Schouten, S., Volkman, J. K., 2014. $C_{27}-C_{30}$ neohop-13(18)-enes and their saturated and aromatic derivatives in sediments: Indicators for diagenesis and water column stratification. Geochimica et Cosmochimica Acta 133: 402-421. DOI: 10.1016/j.gca.2014.03.008.

Slowakiewicz, M., Thomas, L., Tucker, M. E., Ooi, S. M., Whitaker, F. F., Pancost, R. D., 2014. Holocene intertidal microbial mats of Qatar and their implications for petroleum source rock formation in carbonate-siliciclastic-evaporite systems. in: Society of Petroleum Engineers - International Petroleum Technology Conference 2014, IPTC 2014: Unlocking Energy Through Innovation, Technology and Capability. Society of Petroleum Engineers, pp. 1692-1701.

Shirneshan, G., Riyahi Bakhtiari, A., Memariani, M.,

Schnyder, J., Stetten, E., Baudin, F., Pruski, A., Martinez, P., submitted. Fresh terrestrial organic matter delivered to terminal Congo deep-sea fan revealed by Palynofacies. This volume. 
Spencer, R. G. M., Hernes, P. J., Aufdenkampe, A. K., Baker, A., Gulliver, P., Stubbins, A., Aiken, G. R., Dyda, R. Y., Butler, K. D., Mwamba, V. L., Mangangu, A. M., Wabakanghanzi, J. N., Six, J., 2012. An initial investigation into the organic matter biogeochemistry of the Congo River. Geochimica Cosmochimica Acta, 84: 614-627.

Stronkhorst, J., van Hattum, B., 2003. Contaminants of Concern in Dutch Marine Harbor Sediments. Archives of Environmental Contamination and Toxicology, 45: 306-316.

Stetten, E., Baudin, F., Reyss, J.-L., Martinez, P., Charlier, K., Schnyder, J., Rabouille, C., Dennielou, B., Coston-Guarini, J., Pruski, A., 2015. Organic matter characterization and distribution in sediments of the terminal lobes of the Congo deep-sea fan: evidence for the direct influence of the Congo River. Mar. Geol. 369: 182-195.

Sutton, P. A., Lewis, C. A., Rowland, S. J., 2005. Isolation of individual hydrocarbons from the unresolved complex hydrocarbon mixture of a biodegraded crude oil using preparative capillary gas chromatography. Organic Geochemistry 36, pp 963-970.

10. Talbot, H. M, Handley, L., Spencer-Jones, Ch. L;, Dinga, B. J., Schefuß, E., Mann, P. J, Poulsen, J. R, Spencer, R. GM; Wabakanghanzi, J. N., Wagner, T., 2014. Variability in aerobic methane oxidation over the past 1.2Myrs recorded in microbial biomarker signatures from Congo fan sediments. Geochimica et Cosmochimica Acta, 133, 387-401, doi:10.1016/j.gca.2014.02.035.

Tanner, B. R., Uhle, M. E., Mora, C. I., Kelley, J. T., Schuneman, P. J., Lane, C. S., Allen, E. S., 2010. Comparison of bulk and compound-specific $\delta^{13} \mathrm{C}$ analyses and determination of carbon sources to salt marsh sediments using $n$-alkane distributions (Maine, USA). Estuarine, Coastal and Shelf Science 86: 283-291.

Tao, S., Wang, C., Du, J., Liu, L., Chen, Z., 2015. Geochemical application of tricyclic and tetracyclic terpanes biomarkers in crude oils of NW China. Marine and Petroleum Geology, 67: 460-467. http://dx.doi.org/10.1016/j.marpetgeo.2015.05.030.

Tolosa, I., Bayona, J.- M., Albaigés, J., 1996. Aliphatic and polycyclic aromatic hydrocarbons and sulfur/oxygen derivatives in northwestern Mediterranean sediments: spatial and temporal variability, fluxes, and budgets. Environmental Science and Technology 30 : 2495-2503.

11. Treignier C., Saliot, A., Derenne, S., 2006. Terrestrial and marine $n$-alcohol inputs and degradation processes relating to a sudden turbidity current in the Zaire canyon. Organic Geochemistry 37(9):1170-1184 . DOI: 10.1016/j.orggeochem.2006.03.010.

ten Haven, H. L., Rüllkotter, J., 1989. Oleanene, ursine and other terrigeneous triterpenoid biological-marker hydrocarbons in Baffin Bay sediments. Proceedings of the Ocean Drilling Program, Scientific Results, Vol. 105.

Tao, S., Wang, C., Du, J., Liu, L., Chen, Z., 2015. Geochemical application of tricyclic and tetracyclic terpanes biomarkers in crude oils of NW China. Marine and Petroleum Geology, 67 : 460-467. 
Van Bree, L.G.J., Rijpstra, W.I.C. , Al-Dhabi, N.A., Verschuren, D., Sinninghe Damsté J.S., de Leeuw, J.W., 2016. Des-A-lupane in an East African lake sedimentary record as a new proxy for the stable carbon isotopic composition of $\mathrm{C}_{3}$ plants.

Van Dongen, B. E, Talbot, H. M., Schouten, S., Pearson, P. N., Pancost R. D, 2006. Well preserved Palaeogene and Cretaceous biomarkers from the Kilwa area, Tanzania. Organic Geochemistry, 37:539-557.

Vangriesheim A., Khripounoff A., Crassous, P., 2009. Turbidity events observed in situ along the Congo submarine channel. Deep Sea Research II: 56 (2-3): 2208-2222.

Volkman, J.K., 2005. Sterols and other triterpenoids: source specificity and evolution of biosynthetic pathways. Organic Geochemistry, 36: 139-159.

Volkman, J. K., Allen, D. I., Stevenson, P. L., Burton, H. R., 1986. Bacterial and algal hydrocarbons in sediments from a saline Antarctic lake, Ace Lake. In: Leythaeuser, D., Rullkötter, J. (Eds.), Advances in Organic Geochemistry 1985. Pergamon Press, Oxford, pp. 671-681.

Welander, P. V., Coleman, M. L., Sessions, A. L., Summons, R. E., Newman, D. K., 2010. Identification of a methylase required for 2-methylhopanoid production and implications for the interpretation of sedimentary hopanes. Proceedings of the National Academy of Sciences 107.19: 8537-8542. http://dx.doi.org/10.1073/pnas.0912949107.

Zhang, M., Paul, P., 2012. Geochemical characteristics of saturate hydrocarbons in crude oils and source rocks of the Qaidam, Tarim, Tupran basins, NW. Chinese Journal of Geochemistry, 31: 264-275. doi:10.1007/s11631-012-0575-1

Figure 1. Study area. Red dots on the top figure shows the locations of the Congo River sediments K1, K2 and K3, at the entrance to the Malebo Pool. Sediment trap moorings at the Regab site ( $\operatorname{Tr}$ R1 and $\operatorname{Tr} \mathrm{R} 2$ ) at the site WACS $\operatorname{Tr} \mathrm{C}(\operatorname{Tr} \mathrm{C} 1, \operatorname{Tr} \mathrm{C} 2$ and $\operatorname{Tr} \mathrm{C} 4)$ and are indicated by blue triangles. The lower panel shows the general bathymetric map of the Congo River deep-sea fan. The boundaries of the terminal lobe complex are outlined by a black line, while dotted lines outline distinct lobes, from the older lobe 1 to the youngest lobe 5 . The presently active channel fuels the lobe 5 . The locations of coring sites are indicated by black dots. The Site $E$ is located at the end of the abandoned channel. The location of the sediment trap mooring at site A (A-WPPART03) is indicated by a blue triangle.

Figure 2. Molecular profiles of $n$-alkanes in River sediments (K1), in sediment traps collected during WACS at $3420 \mathrm{~m}$ ( $\operatorname{TrC1})$ and at the site A (TrA1), and in surficial $(0$ to $0.5 \mathrm{~cm}$ ) 
sediments collected in the terminal lobe complex, in the levee of site $C$ (CL $0-0.5$ ), in the channel of site C (CC 0-0.5) and at site E (E 0-0.5). $n$-Alkane homologues are assigned by their carbon number, and their abundance is expressed as concentrations, in ng per gram of dry weight (ng $\mathrm{DDw}^{-1}$ ).

Figure 3. Top panel shows the spatial distribution of terrestrial $n$-alkane concentrations normalized to organic carbon, in sediments from the Congo River (grey bars), in surficial sediments collected from the Congo deep sea fan (black bars, Lev: levee, Cha: channel, sediment layers from 0 to $0.5 \mathrm{~cm}$ and from 0.5 to $1 \mathrm{~cm}$ ), and in sediment trap samples (white bars). Terrestrial $n$-alkanes are defined here as odd $n$-alkanes from $C_{25}$ to $C_{37}$. $n$-Alkanes levels are expressed in $\mathrm{ng}$ per gram of organic carbon $\left(\mathrm{ng} \mathrm{goc}{ }^{-1}\right)$. Carbon Preference Index (CPI) calculated from $\mathrm{C}_{25}$ to $\mathrm{C}_{35}$ is plotted on the right axis. Bottom panels show the vertical profiles of terrestrial $n$-alkane concentrations and CPI in two cores, from the channel at site $C$, and from site $E$.

Figure 4. Top panel shows the spatial distribution of $C_{16} n$-alkane concentrations normalized to organic carbon, in sediments from the Congo River (grey bars), in surficial sediments collected from the Congo deep sea fan (black bars, Lev: levee, Cha: channel, sediment layers from 0 to $0.5 \mathrm{~cm}$ and from 0.5 to $1 \mathrm{~cm}$ ), and in sediment trap samples (white bars). $C_{16}$ levels are expressed in $\mathrm{ng}$ goc $^{-1}$. Bottom panels show the vertical profiles of $\mathrm{C}_{16}$ concentration in two cores, from the channel at site $C$, and from site $E$. The star indicates petroleum contamination, in this sample the low molecular mode of alkane showed no even predominance.

Figure 5. Top panel shows the spatial distribution of phytadiene concentrations normalized to organic carbon, in sediments from the Congo River (grey bars), in surficial sediments collected from the Congo deep sea fan (black bars, Lev: levee, Cha: channel, sediment layers from 0 to $0.5 \mathrm{~cm}$ and from 0.5 to $1 \mathrm{~cm}$ ), and in sediment trap samples (white bars). The sum of three phytadiene levels are expressed in $\mathrm{ng} \mathrm{goc}^{-1}$. Bottom panels show the vertical profiles of concentration of phytadienes, in two cores, from the channel at site $\mathrm{C}$, and from site $\mathrm{E}$.

Figure 6. Molecular profiles of dominant triterpenes in River sediments (K1), in sediment traps collected during WACS at $3420 \mathrm{~m}(\operatorname{TrC} 1)$ and at the site A (TrA1), and in surficial (0 to $0.5 \mathrm{~cm}$ ) sediments collected in the terminal lobe complex, in the levee of site A (AL 0-0.5), in the channel of site $C(C C 0-0.5)$ and at site $E$ (E 0-0.5). Hopanes, hopenes and other triterpenes are quantified as peak area in the fragmentogram $\mathrm{m} / \mathrm{z}=191$, and by relating their area to the area of hop-17(21)-ene, quantified by GC-FID. Triterpene levels are expressed in ng $g_{D W}{ }^{-1}$. 
Figure 7. Top panel shows the spatial distribution of gammacerene concentrations normalized to organic carbon, in sediments from the Congo River (grey bars), in surficial sediments collected from the Congo deep sea fan (black bars, Lev: levee, Cha: channel, sediment layers from 0 to $0.5 \mathrm{~cm}$ and from 0.5 to $1 \mathrm{~cm}$ ), and in sediment trap samples (white bars). Fernene level is represented by white circles, plotted on the right axis. Gammacerene and fernene are terrestrial biomarkers, while fernene can also be sourced by microorganisms. Their levels are expressed in $\mathrm{ng} \mathrm{goc}^{-1}$. Bottom panels show the vertical profiles of concentration of gammacerene and fernene, in two cores: from the channel at site $\mathrm{C}$, and from site $\mathrm{E}$.

Figure 8. The top panel shows the spatial distribution of the concentrations of $C_{31} \beta \beta$ homohopane normalized to organic carbon, in sediments from the Congo River (grey bars), in surficial sediments collected from the Congo deep sea fan (black bars, Lev: levee, Cha: channel, sediment layers from 0 to $0.5 \mathrm{~cm}$ and from 0.5 to $1 \mathrm{~cm}$ ), and in sediment trap samples (white bars). $C_{31} \beta \beta$-homohopane levels are expressed in $\mathrm{ng} \mathrm{goc}^{-1}$. White circles represent the mean grain size of the lobe complex sediment, in $\mu \mathrm{m}$ and is plotted on the right axis. Bottom panels show the vertical profiles of concentration of $C_{31} \beta \beta$-homohopane and of mean grain size, in two cores: from the channel at site $C$, and from site $E$.

Figure 9. Top panel shows the spatial distribution of diploptene concentrations normalized to organic carbon, in sediments from the Congo River (grey bars), in surficial sediments collected from the Congo deep sea fan (black bars, sediment layers from 0 to $0.5 \mathrm{~cm}$ and from 0.5 to $1 \mathrm{~cm}$ ), and in sediment trap samples (white bars). Hop-21-ene concentration is represented by white circles, plotted on the right axis. Diploptene is a terrestrial biomarker (soil microorganisms), and marine bacteria can also be its biological precursor. Diploptene and hop-21-ene levels are expressed in $\mathrm{ng} \mathrm{goc}^{-1}$. Bottom panels show the vertical profiles of concentration of diploptene and hop-21-ene, in two cores: from the channel at site $C$, and from site $\mathrm{E}$.

Figure 10. Scatter plots of OC-normalized concentrations of selected terpenoids versus gammacerene concentration. Gammacerene is a synthesized by ferns and bacteria. In the Congo terminal lobe system, it covariates with $\delta^{13} \mathrm{C}$, therefore have a terrestrial origin.

Figure 11. The top panel shows the spatial distribution of neohop-13(18)-ene concentrations normalized to organic carbon, in sediments from the Congo River (grey bars), in surficial sediments collected from the Congo deep sea fan (black bars, Lev: levee, Cha: channel. sediment layers from 0 to $0.5 \mathrm{~cm}$ and from 0.5 to $1 \mathrm{~cm}$ ), and in sediment trap samples (white bars). Concentrations of hop-17(21)-ene are represented by white cercles plotted on the right axis. Diploptene and hop-17(21)-ene levels are expressed in ng goc $^{-1}$. Bottom panels 
show the vertical profiles of concentration of neohop-13(18)-ene and hop-17(21)-ene, in two cores: from the channel at site $\mathrm{C}$, and from site $\mathrm{E}$.

Figure 12. Hydrocarbon accumulation rates in sediments from sites $A, F$ and $C$ are represented by back bars. Hydrocarbon sedimentation fluxes, measured by sediment traps 40 meters above the sediment are showed by white bars. Selected hydrocarbons are the dominant terrestrial alkane, $n-C_{29}$, an terrestrial indicator, gammacerene, and diploptene. Diploptene has a dual source, from terrestrial and marine bacteria. Fluxes are given in $\mathrm{ng} \mathrm{m}^{-2}$ $\mathrm{yr}^{-1}$.

Table 1 : Sample name used in the figures, sample label, sample location, depth of collection of the sample, numbers of studied samples at a given site and characteristics of the sample series (core depth horizons or time intervals).

Name Congolobe Label Latitute $\left({ }^{\circ} \mathrm{S}\right) \quad$ Longitude $\left({ }^{\circ} \mathrm{E}\right) \cup$ Depth Analyzed sample number

K1 (bedload) $\quad 04^{\circ} 05 \quad 15^{\circ} 31$

K2 (river bank) $\quad \begin{array}{llll}04^{\circ} 18 & 15^{\circ} 21 & - & 1\end{array}$

$\begin{array}{lllll}\text { K3 (floodplain) } & 05^{\circ} 57 & 12^{\circ} 49 & - & 1\end{array}$

$\begin{array}{lllll}\text { A Levee } & \text { COL-A-MTB-02 } & 06^{\circ} 27^{\prime} & 06^{\circ} 02^{\prime} & 4759 m\end{array}$

sediment horizons,

Depth intervals in $\mathrm{cm}$ : $0-0.5 ; 0.5-1$

$\begin{array}{lllll}\text { A Channel COL-A-MTB-03 } & 06^{\circ} 28^{\prime} & 06^{\circ} 02^{\prime} & 4774 \mathrm{~m} & 2\end{array}$ sediment horizons,

Depth intervals in $\mathrm{cm}$ : $0-0.5 ; 0.5-1$

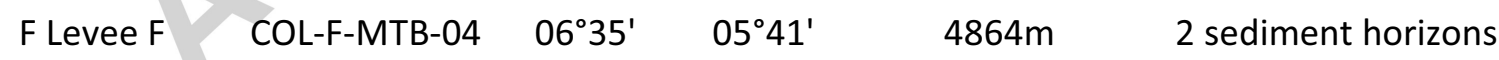

Depth intervals in $\mathrm{cm}$ : $0-0.5 ; 0.5-1$

C Levee COL-C-MTB-06 $\quad 06^{\circ} 40^{\prime} \quad 05^{\circ} 28^{\prime} \quad 4951 \mathrm{~m} \quad 2 \quad$ sediment horizons

$4951 \mathrm{~m}$

Depth intervals in $\mathrm{cm}$ : $0-0.5 ; 0.5-1$

$\begin{array}{llllll}\text { C Channel COL-C-MTB-11 } & 06^{\circ} 42^{\prime} \quad 05^{\circ} 29^{\prime} & 4960 m & 10 & \text { sediment }\end{array}$ horizons 
Depth intervals in $\mathrm{cm}$ :

$0-0.5 ; \quad 0.5-1 ; \quad 1-2 ; \quad 3-5 ;$

5-7;

$7-10 ; 10-13 ; 13-16 ; 16-$ $19 ; 19-22$

B

COL-B-MTB-12 $\quad 06^{\circ} 25^{\prime} \quad 05^{\circ} 49^{\prime}$

$4823 \mathrm{~m} \quad 2$ sediment horizons

Depth intervals in $\mathrm{cm}$ : $0-0.5 ; 0.5-1$

E

COL-E-MTB-14 $\quad 06^{\circ} 06^{\prime} \quad 05^{\circ} 54^{\prime}$

$4750 m$

11 sediment horizons

5; 5-7;

$13 ; 13-16 ; 16-19 ; 19-22$

TrR1 , TrR2 (Regab)

$05^{\circ} 48 \quad 09^{\circ} 43$

$3151 m$

$\operatorname{TrC1}, \operatorname{TrC2}, \operatorname{TrC} 4$

$05^{\circ} 48$

$09^{\circ} 43$

$3420 \mathrm{~m}$

in 2011

TrA1 TrA2 WACS-A-PPART03 $06^{\circ} 286^{\circ} 02^{\prime}$

$4717 m$

2 time intervals in 2011:

Feb 13th-March $14^{\text {th }}$,

March $14^{\text {th }}-29^{\text {th }}$

3 time intervals $7-10 ; 10-$

Depth intervals in $\mathrm{cm}$ :

$0-0.5 ; 0.5-1 ; 1-2 ; 2-3 ; 3-$

Feb 13th-March $14^{\text {th }}$, March $\quad 14^{\text {th }}-29^{\text {th }}$, April13 $3^{\text {th }}-28^{\text {th }}$

2 time intervals in 2011

Feb 13th-March $14^{\text {th }}$, March $14^{\text {th }}-29^{\text {th }}$

Table 2. Source assignment of hydrocarbon biomarkers detected in the present study.

Biomarker Source organisms Source environment References 
$\mathrm{C}_{25}-\mathrm{C}_{35}$ odd alkanes waxes of higher plants

Eglinton et al., 1962; Eglinton and Hamilton, 1967

$\mathrm{C}_{17}$

phytoplankton

Clark and Blumer, 1967

$\mathrm{C}_{16}, \mathrm{C}_{18}$

bacteria

Grimalt and Albaigés, 1987; Nishimura and Baker, 1986

$$
\begin{aligned}
& \text { grass } \\
& \text { et al., } 2010 \\
& \text { sedimentary rocks } \\
& \text { et al., } 2016
\end{aligned}
$$

petroleum

Tao et al., 2016

Phytadienes

reducing environment

Grossi et al., 1998

UCM

petroleum

Broman et al., 1987

Gammacerene

ciliates, ferns, bacteria terrestrial inputs

marine marine

$$
\text { terrestrial }
$$

terrestrial

Tao
Kuhn

oil input

marine

oil input

terrestrial, marine

Bravo

et al.,

2001;

Hame

$d$ et

al.,

2014;

Kleem

ann

et al., 1990,

Banta

et al.

2015 


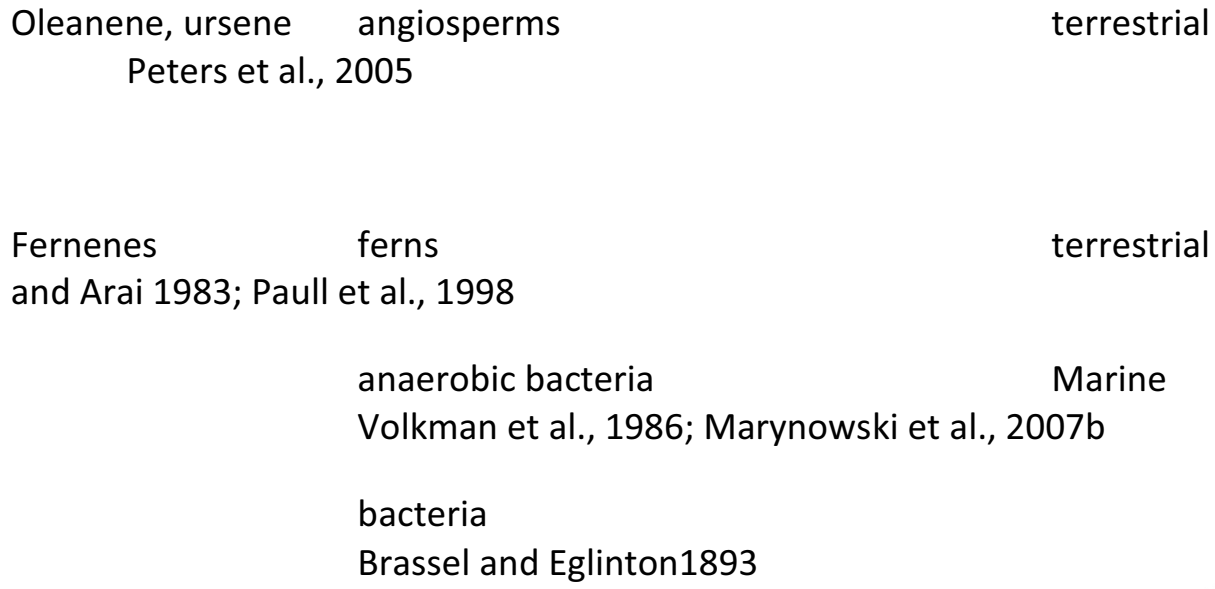

Table 3. Concentration levels ( $\mathrm{ng} \mathrm{gDw}^{-1}$ and $\mathrm{ng}_{\mathrm{oc}}{ }^{-1}$ ) and fluxes $\left(\mu \mathrm{g} \mathrm{m}^{-2} \mathrm{yr}^{-1}\right.$ ) of terrestrial alkanes, Short-chain alkanes, UCM and terpenoids in marine, lacustrine and continental sediments in comparison with sediments from the terminal Congo lobe system.

\begin{tabular}{|c|c|c|c|c|c|}
\hline $\begin{array}{l}\text { Study } \\
\text { location }\end{array}$ & Terrestrial alkanes & $\begin{array}{l}\text { Short-Chain } \\
\text { alkanes C16 } \\
+ \text { C18 }\end{array}$ & UCM & Terpenoids & $\begin{array}{l}\text { Referen } \\
\text { ce }\end{array}$ \\
\hline
\end{tabular}




\begin{tabular}{|c|c|c|c|c|c|c|c|c|c|c|c|}
\hline & & $\begin{array}{l}\mu \mathrm{g} \\
\mathrm{m}^{-2}\end{array}$ & $\mathrm{ng}$ & $\mu \mathrm{g}$ & $\begin{array}{l}\mu \mathrm{g} \\
\mathrm{m}^{-2}\end{array}$ & & $\mu \mathrm{g}$ & & $\mathrm{ng}$ & $\mu \mathrm{g}$ & $\begin{array}{l}\mu \mathrm{g} \\
\mathrm{m}^{-2}\end{array}$ \\
\hline $\mathrm{ng}^{-1}$ & $g_{-1}$ & $\begin{array}{c}\mathrm{yr}- \\
1\end{array}$ & $g_{D_{1}}$ & $g^{-1}$ & $\begin{array}{c}\mathrm{yr}- \\
1\end{array}$ & $\mathrm{ng}^{-1}$ & $\begin{array}{l}\mathrm{m}^{-2} \\
\mathrm{yr}^{-1}\end{array}$ & $\square$ & $g_{D W}$ & $g_{0}$ & yr- \\
\hline
\end{tabular}

\section{Atlantic}

Ocean

SE $\quad$ C27

margin, -

including C33

Congo fan odd

20 -

290 nc

nc

Rommerk

irshen et

SE

margin, C25 460 -

including $-35 \quad 39$

Congo fan odd 000

6,0

$00 \mathrm{nc}$

nc

Schefuss

2004

66.

0 -

\begin{tabular}{|c|c|}
\hline Congo & \\
\hline River & $\mathrm{C} 23$ \\
\hline
\end{tabular}

$\begin{array}{lll}\text { particles } & -35 & .1\end{array}$

Hemingw

ay et al.,

2016

\begin{tabular}{|c|c|c|c|c|c|c|c|c|c|c|c|c|c|}
\hline & $\mathrm{C} 25$ & & 2.2 & 0.2 & nd nd & $\gamma$ & & nd- & & & nd & & \\
\hline Congo & - & & - & $3-$ & $-\quad-$ & & nd - & 2 & Neo & & - & & \\
\hline deep sea & 350 & $30-$ & 56. & 27 & $\begin{array}{ll}35 & 16\end{array}$ & nd- & 1047 & 05 & hop & nd- & 2. & nd & This \\
\hline & $d d$ & 2050 & 4 & 02 & $\begin{array}{lll}0 & 4\end{array}$ & 651 & 0 & 0 & ene & 69 & 85 & -68 & study \\
\hline & & & & & & & & & & & nd & & \\
\hline Congo & & & & & & & & & Dipl & & - & nd & \\
\hline deep sea & & & & & & & & & opt & nd- & 7. & - & This \\
\hline fan & & & & & & & & & ene & 303 & 34 & 249 & study \\
\hline Southwes & & & & & & & & & & & & & \\
\hline t African & & 2000 & & & & & & & & & & & Hermann \\
\hline coast C25- & & -31 & & & & & & & & & & & et al., \\
\hline 33 & & 000 & & & $\mathrm{nc}$ & & & nc & & nc & & & 2016 \\
\hline \multicolumn{14}{|l|}{ Washingt } \\
\hline on Coast & & & & & & & & & Dipl & & & & \\
\hline C25-31 & & $600-$ & & & & & & & opt & $30-$ & & & Prahl et \\
\hline \multirow[t]{2}{*}{ odd } & & 2500 & & & $\mathrm{nc}$ & & & $\mathrm{nc}$ & ene & 500 & & & al., 1992 \\
\hline & $\mathrm{C} 29$ & & & & & & & & & & & & \\
\hline Amazon & $+\mathrm{C} 3$ & $46-$ & & & & & & & & & & & Haggi et \\
\hline estuary & 1 & 424 & & & $\mathrm{nc}$ & & & $\mathrm{nc}$ & & nc & & & al., 2016 \\
\hline Brazilian & $\mathrm{C} 21$ & $100-$ & & & $\mathrm{nc}$ & & & $\mathrm{nc}$ & & nc & & & Maciel et \\
\hline
\end{tabular}




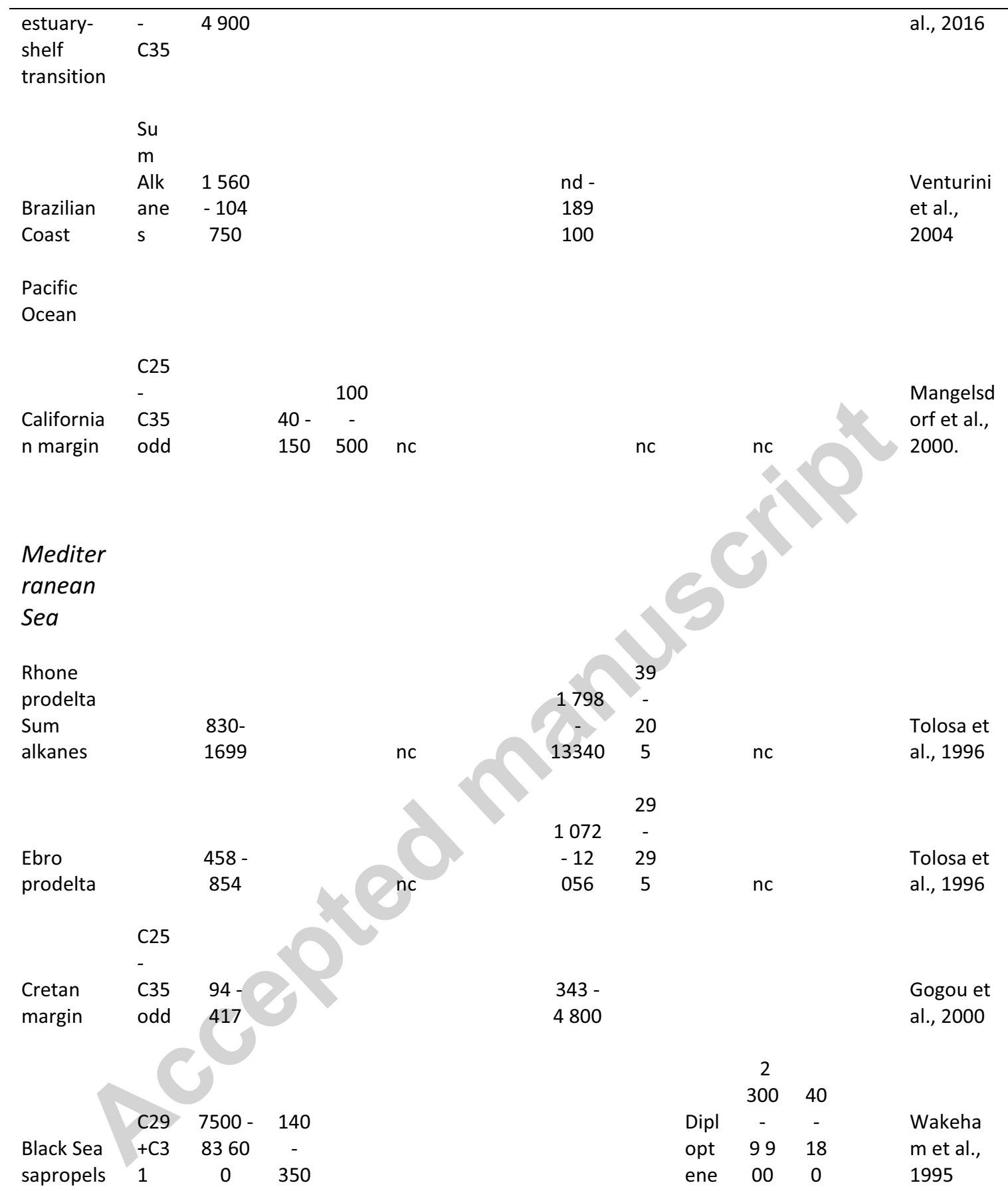

\section{Pacific \\ Ocean}

\begin{tabular}{|c|c|c|c|c|c|c|}
\hline Yangtze & $\begin{array}{l}\text { C15 } \\
-38\end{array}$ & $\begin{array}{l}160- \\
1880\end{array}$ & & $\begin{array}{l}\text { Hop } \\
\text { ane }\end{array}$ & $\begin{array}{l}\text { ca } \\
2- \\
11\end{array}$ & $\begin{array}{l}\text { Boulouba } \\
\text { ssi et al., }\end{array}$ \\
\hline estuary & -38 & 1880 & & & 11 & \\
\hline Yellow & C15 & $240-$ & $6-$ & & & Liu et al., \\
\hline Sea & -35 & 1340 & 47 & & & 2012 \\
\hline
\end{tabular}




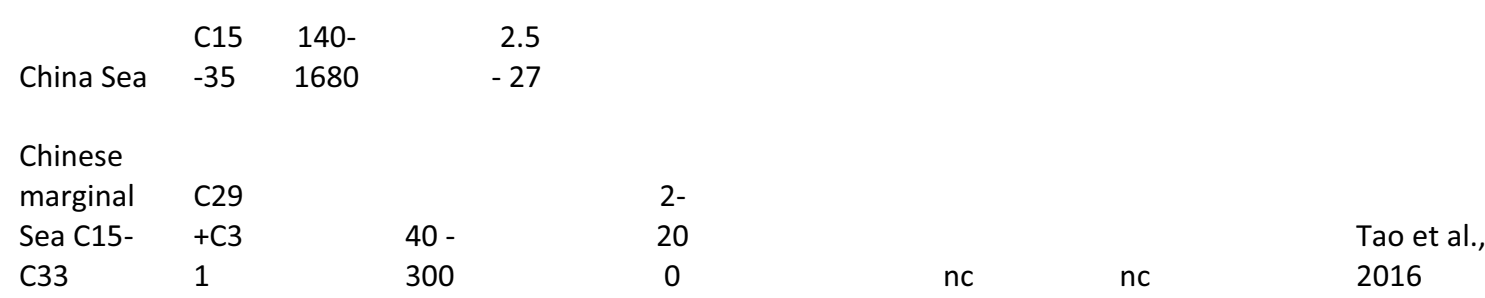

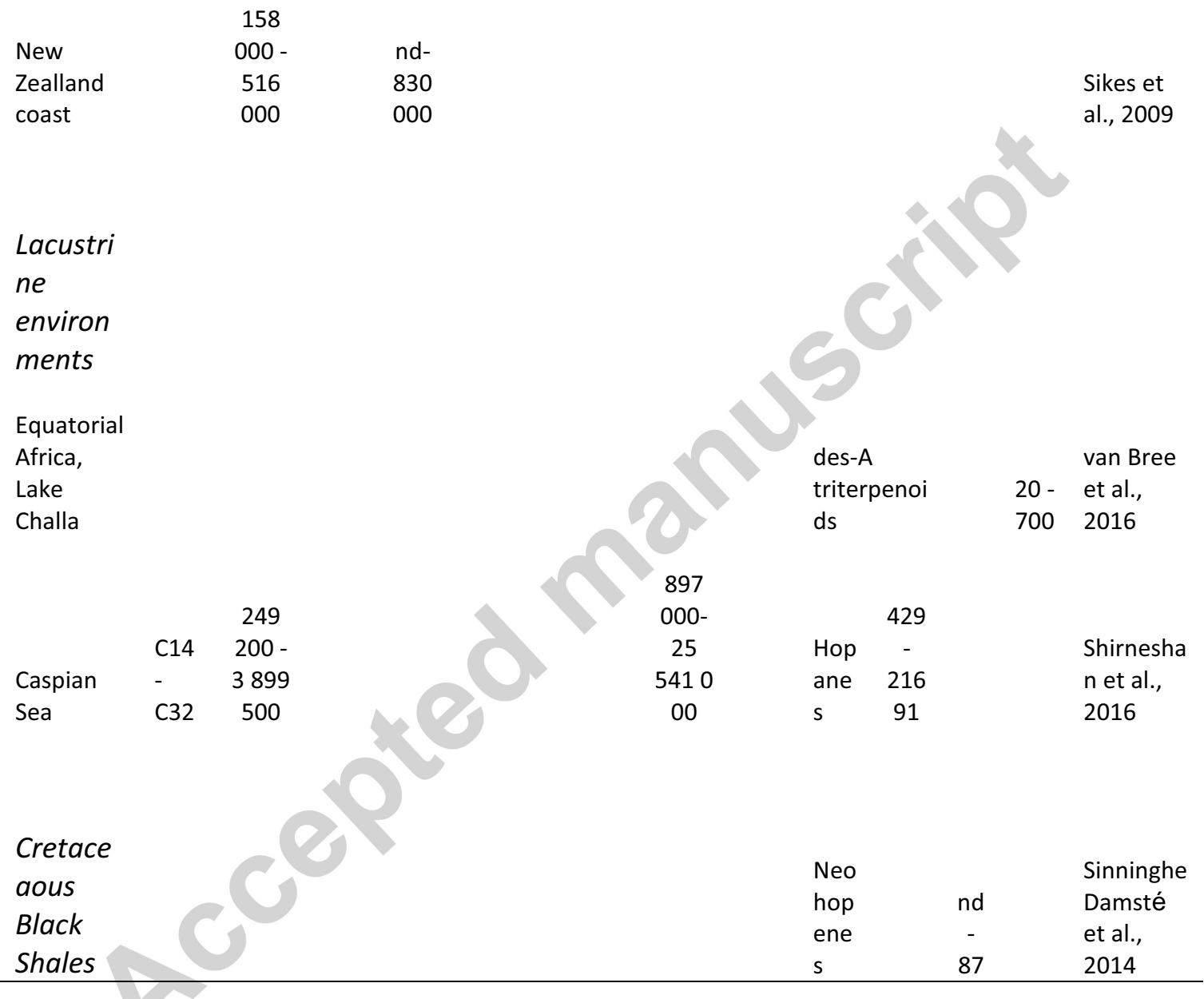




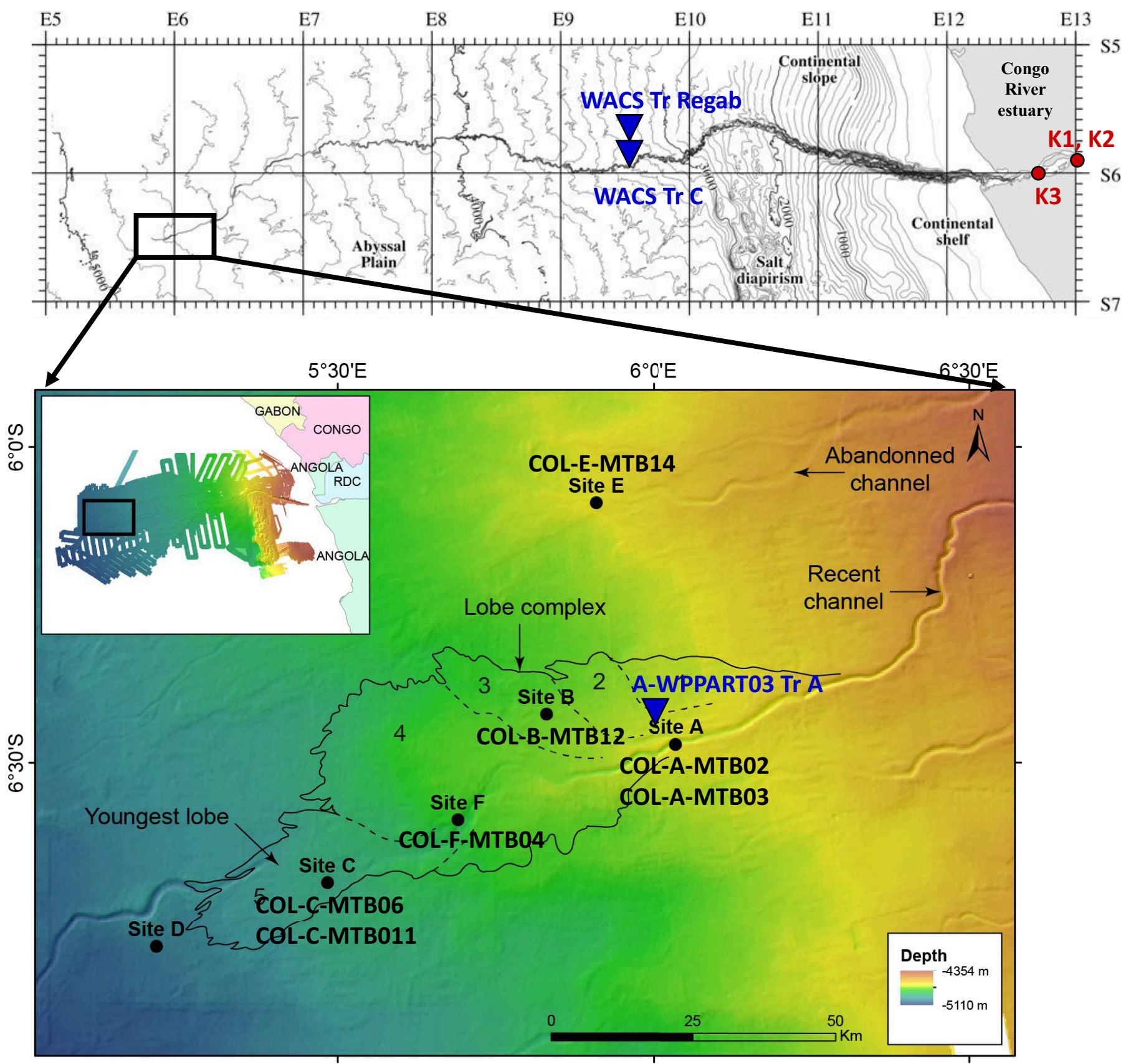

Figure 1 
Figure 2
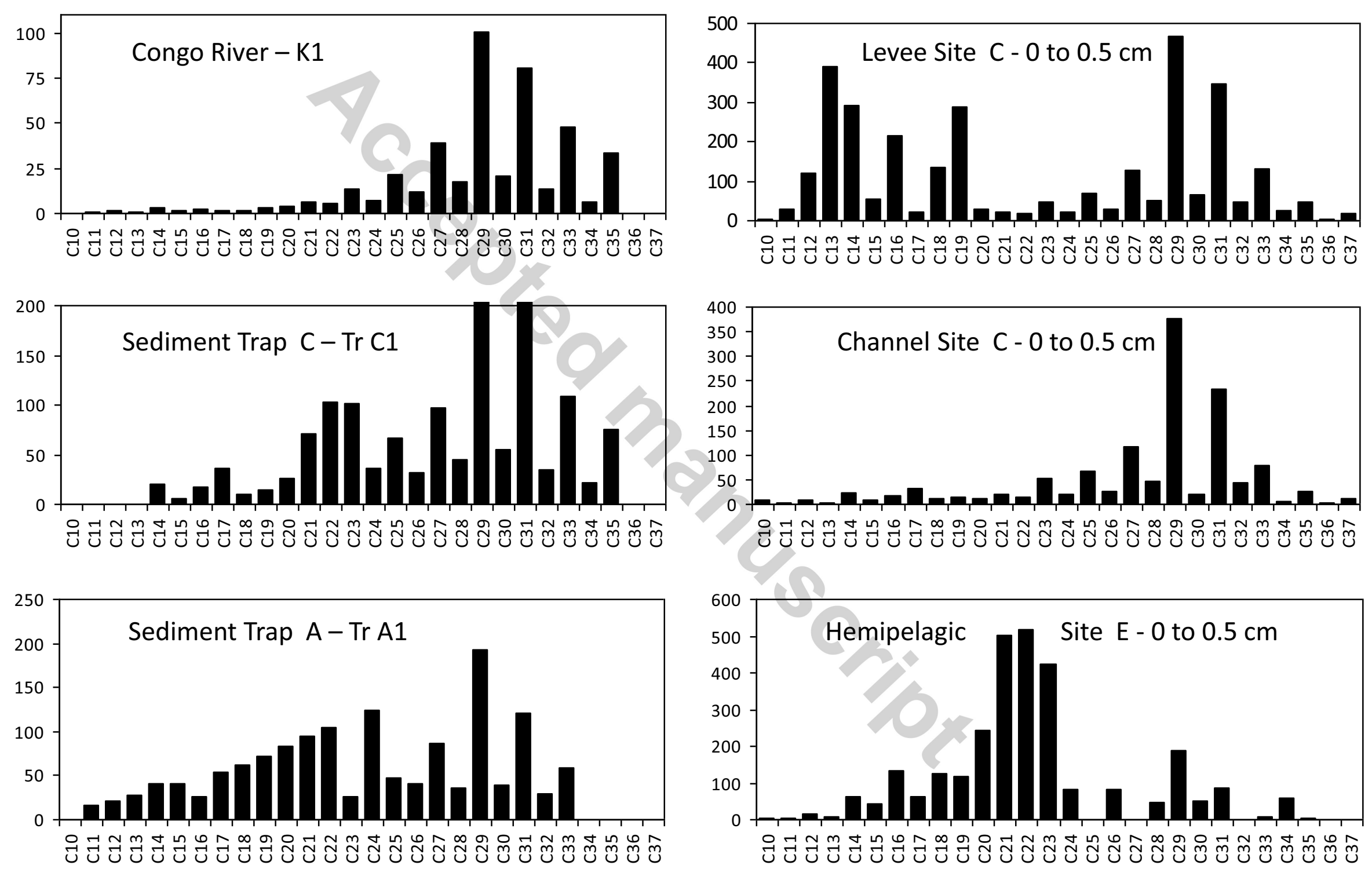


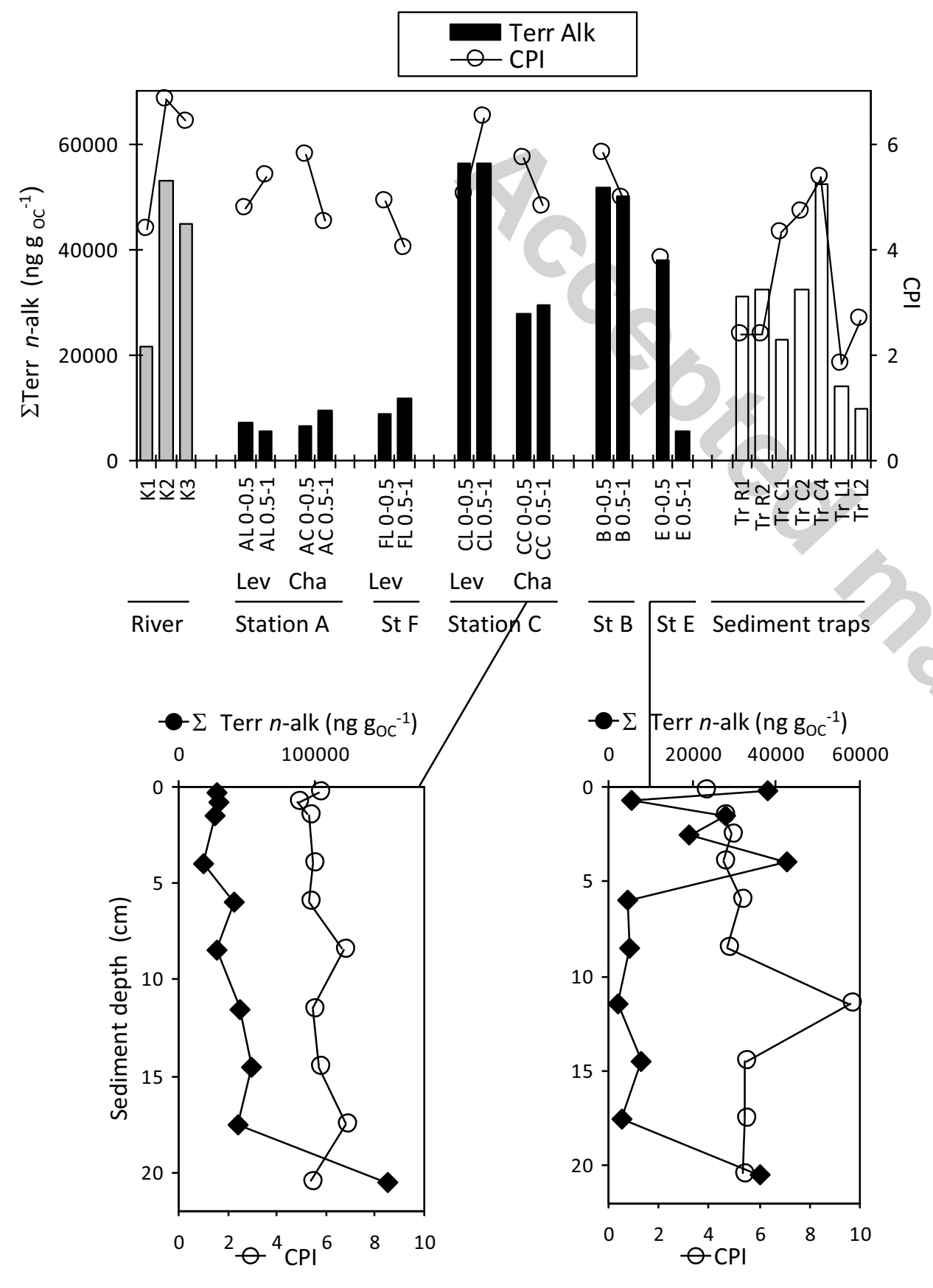

Figure 3 


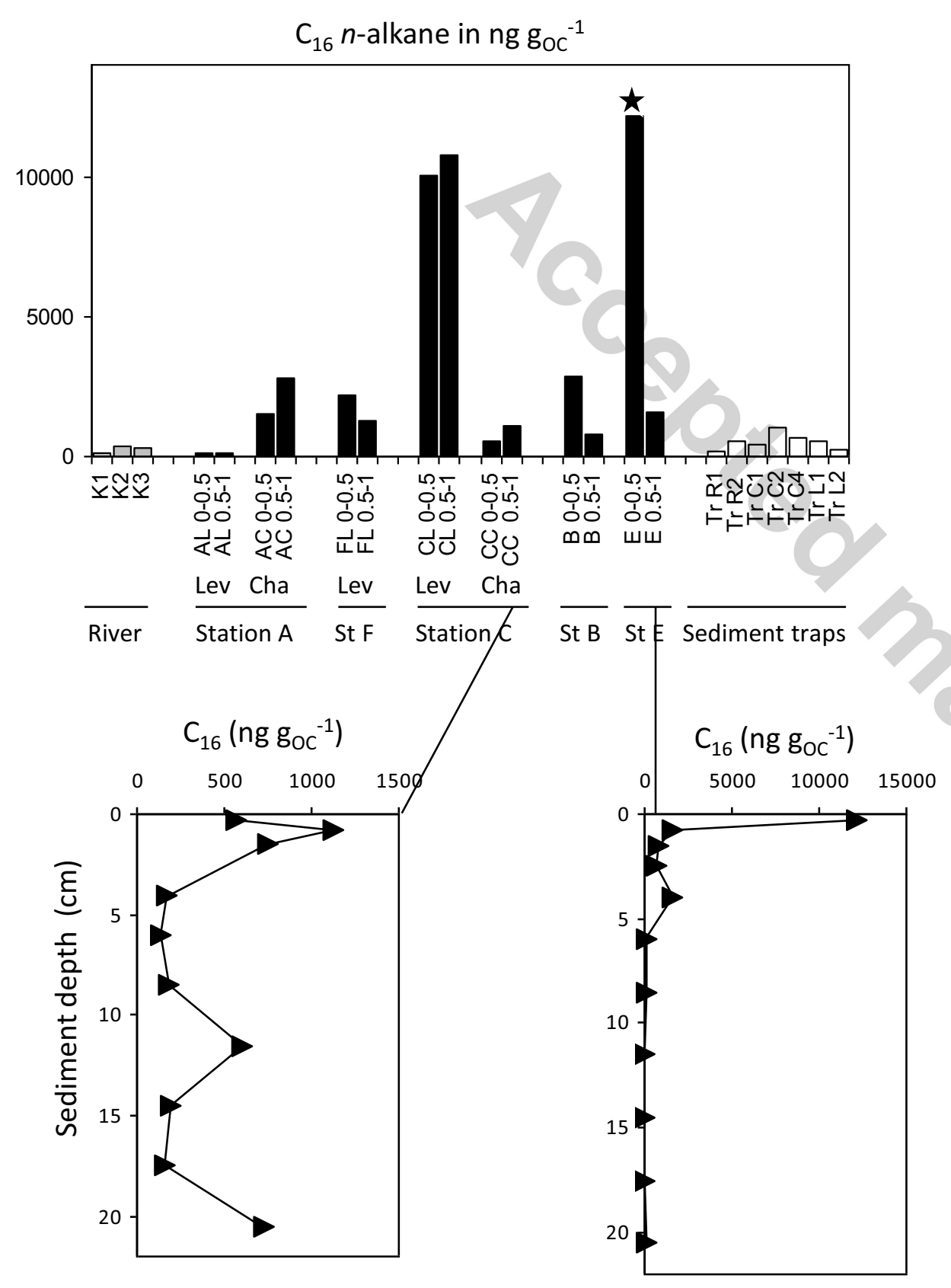

Figure 4 


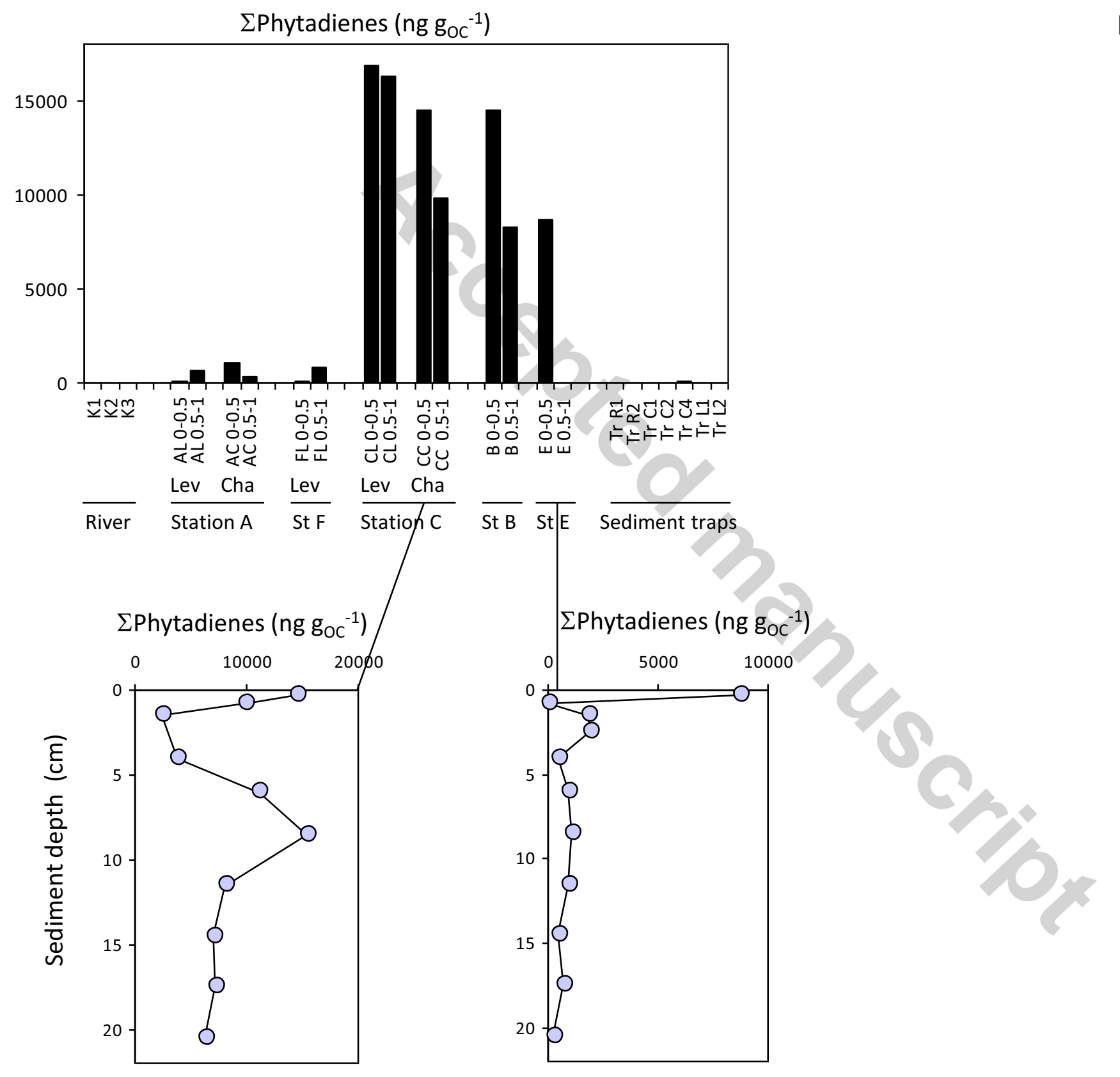

Figure 5 

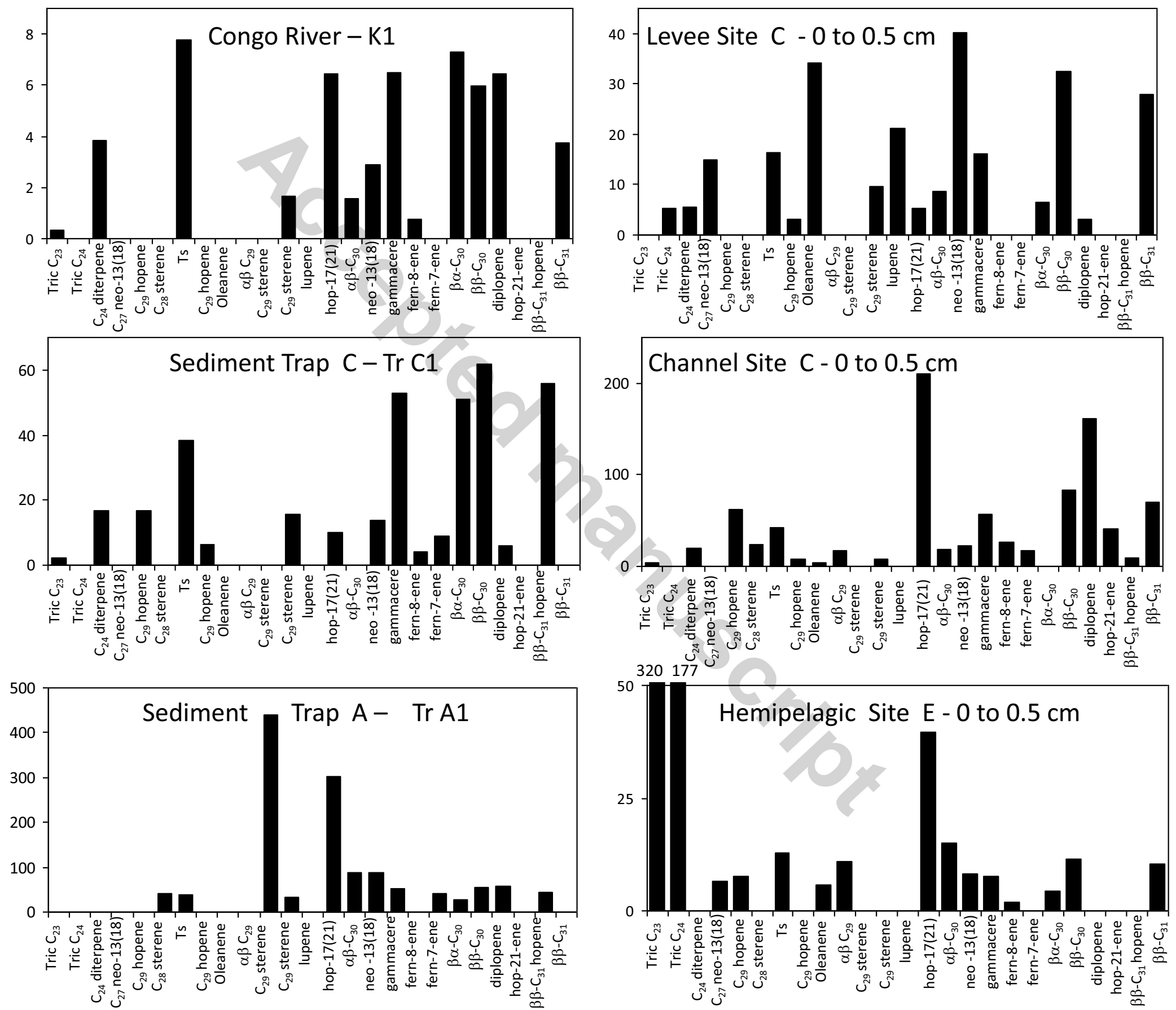


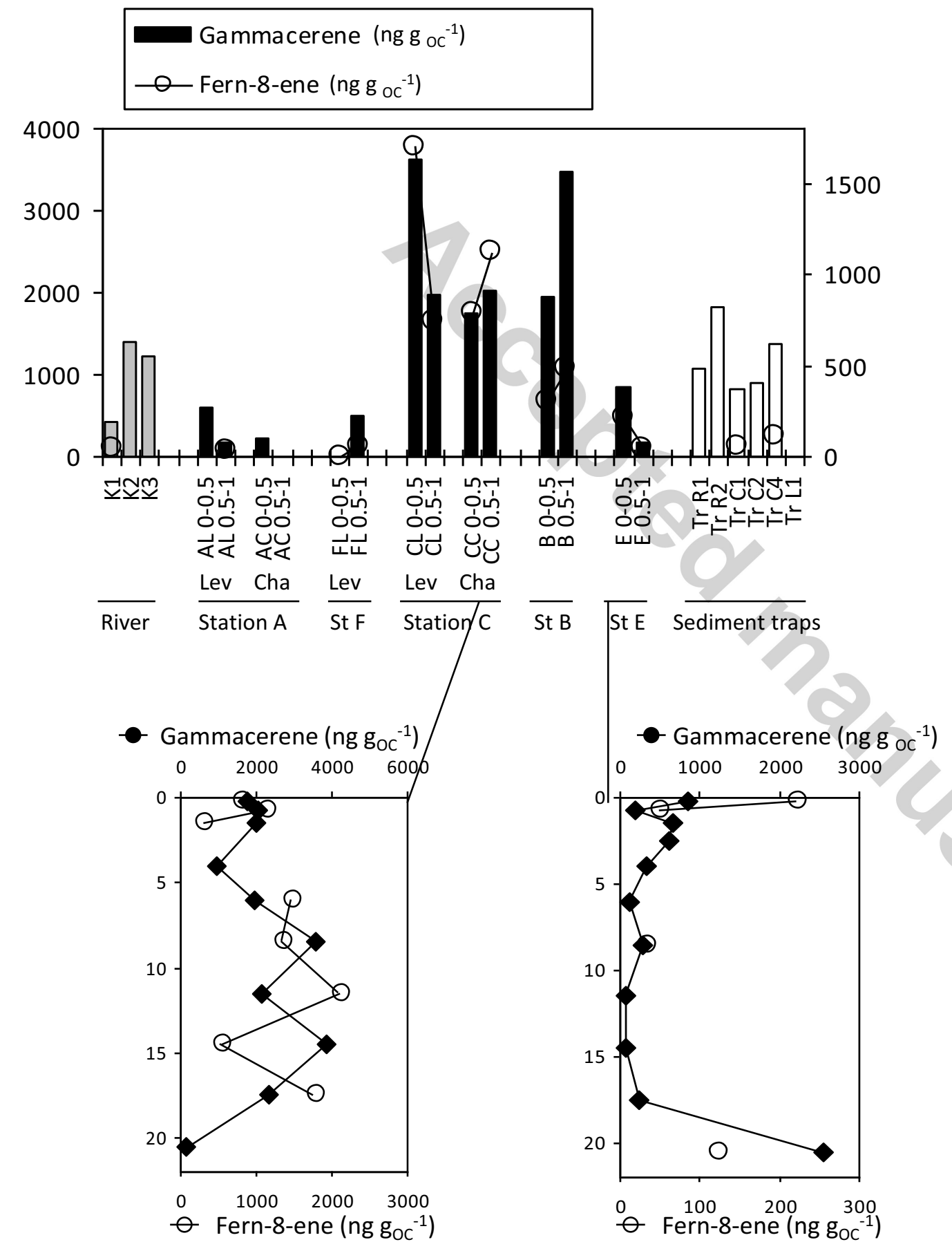

Figure 7 


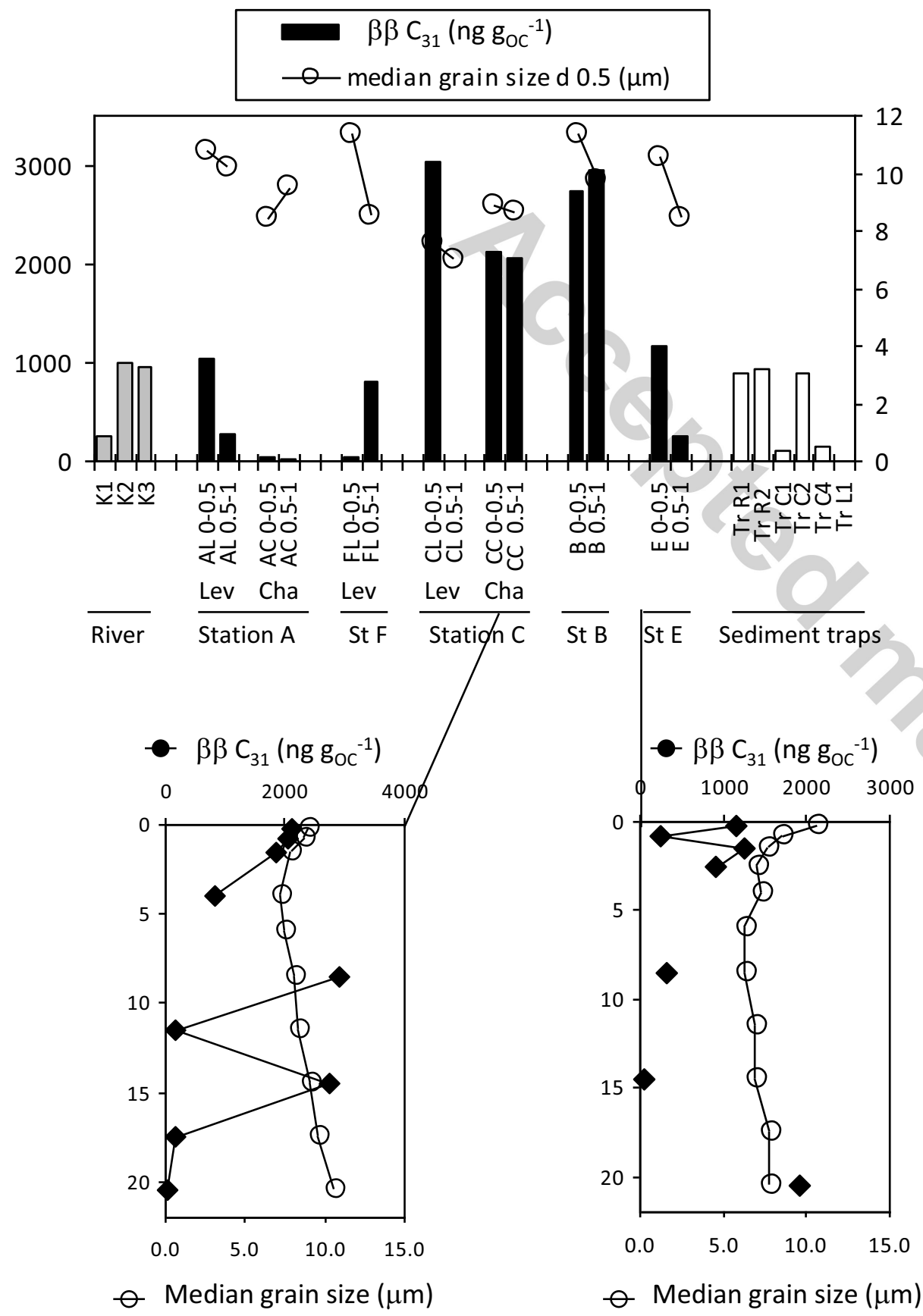

Figure 8 


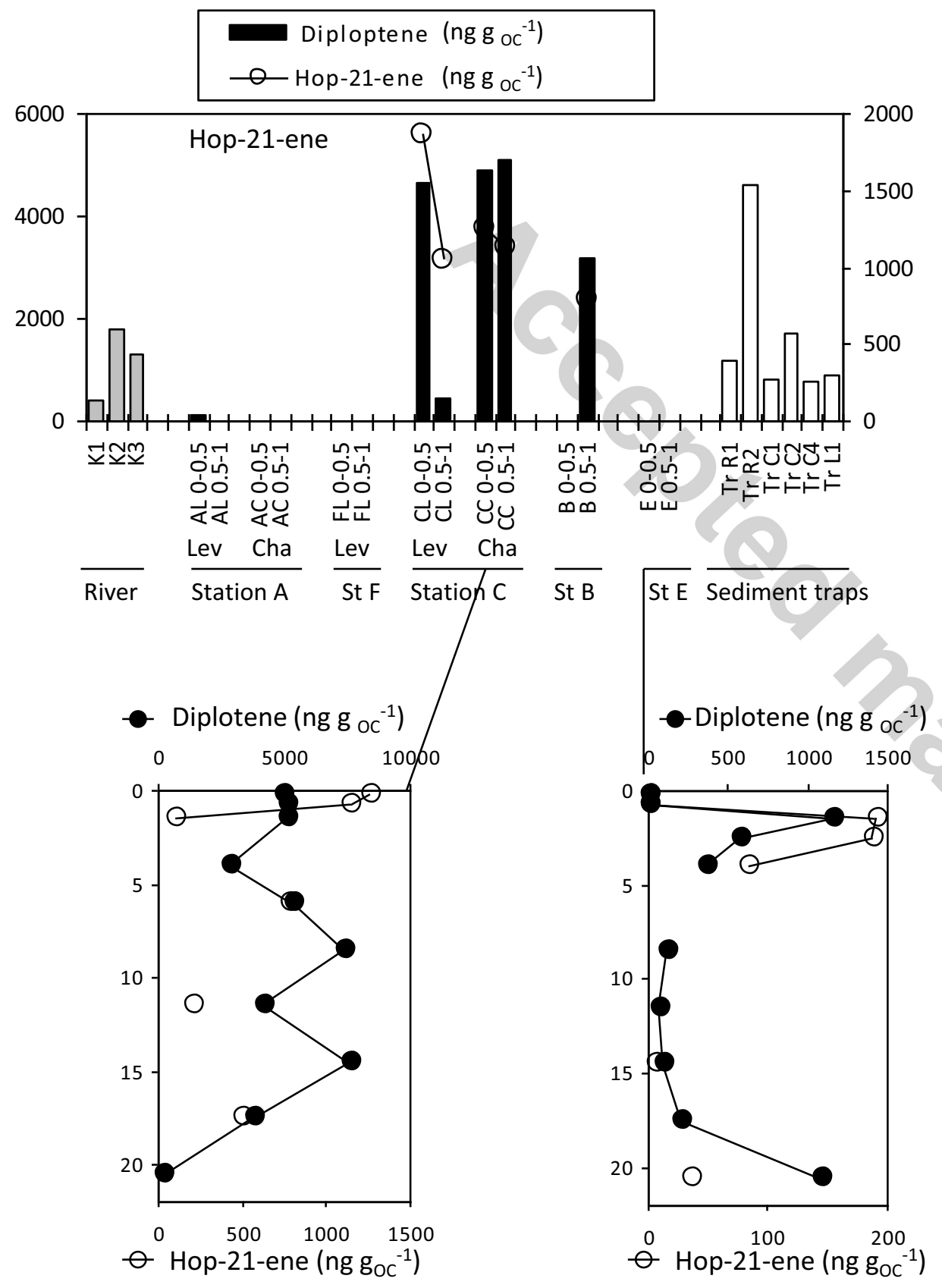

Figure 9 
Figure 10
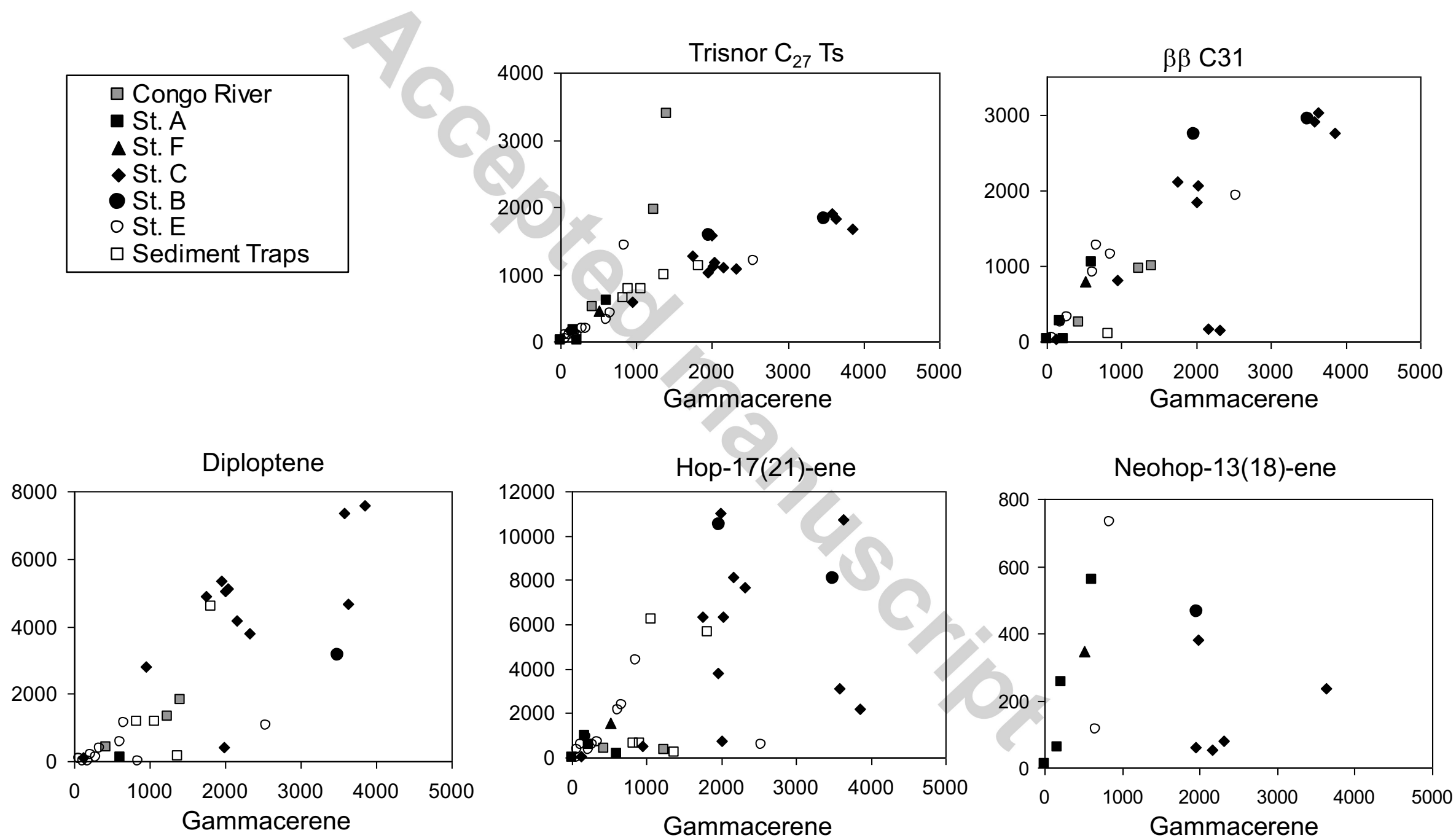


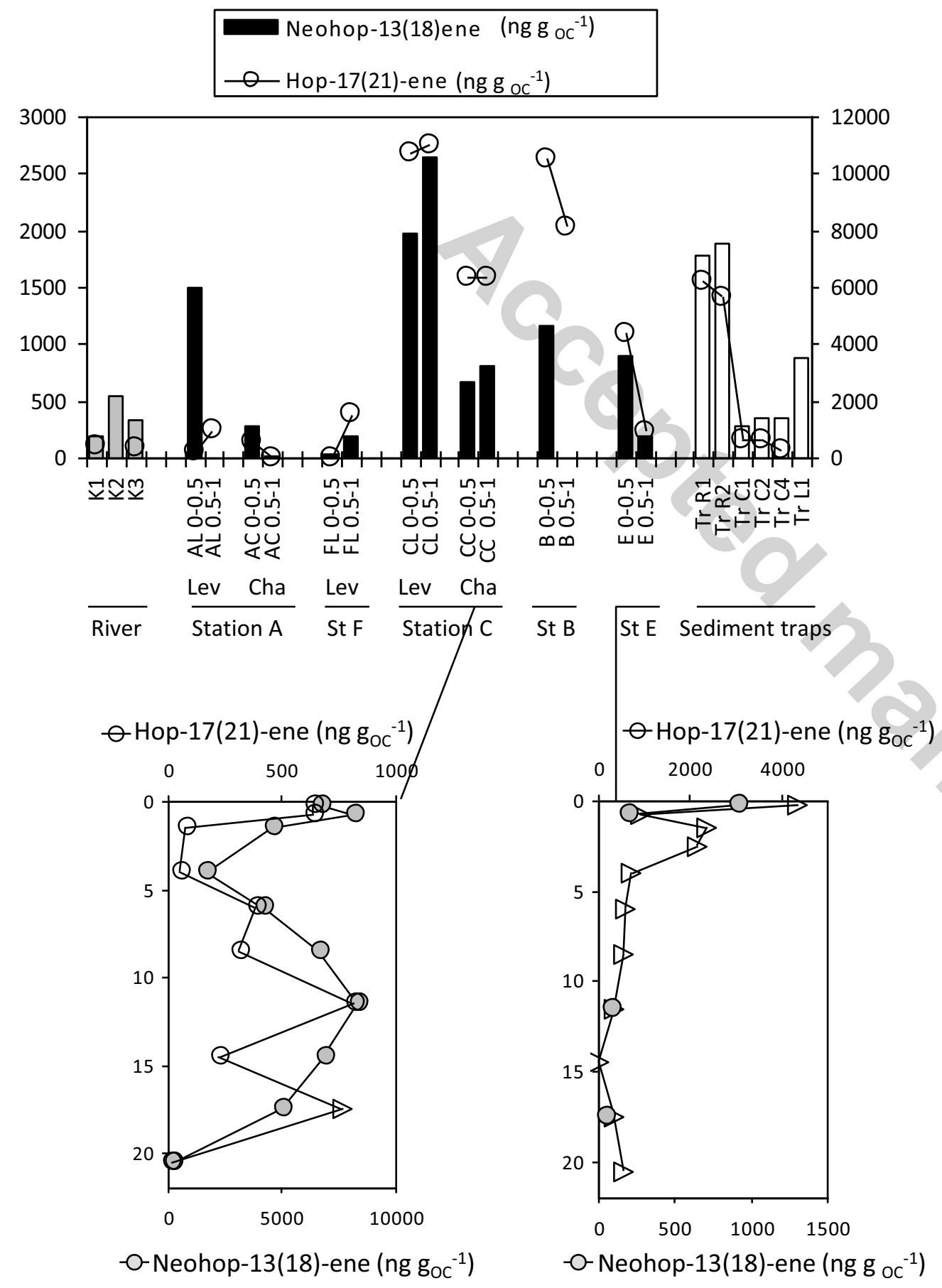

Figure 11 


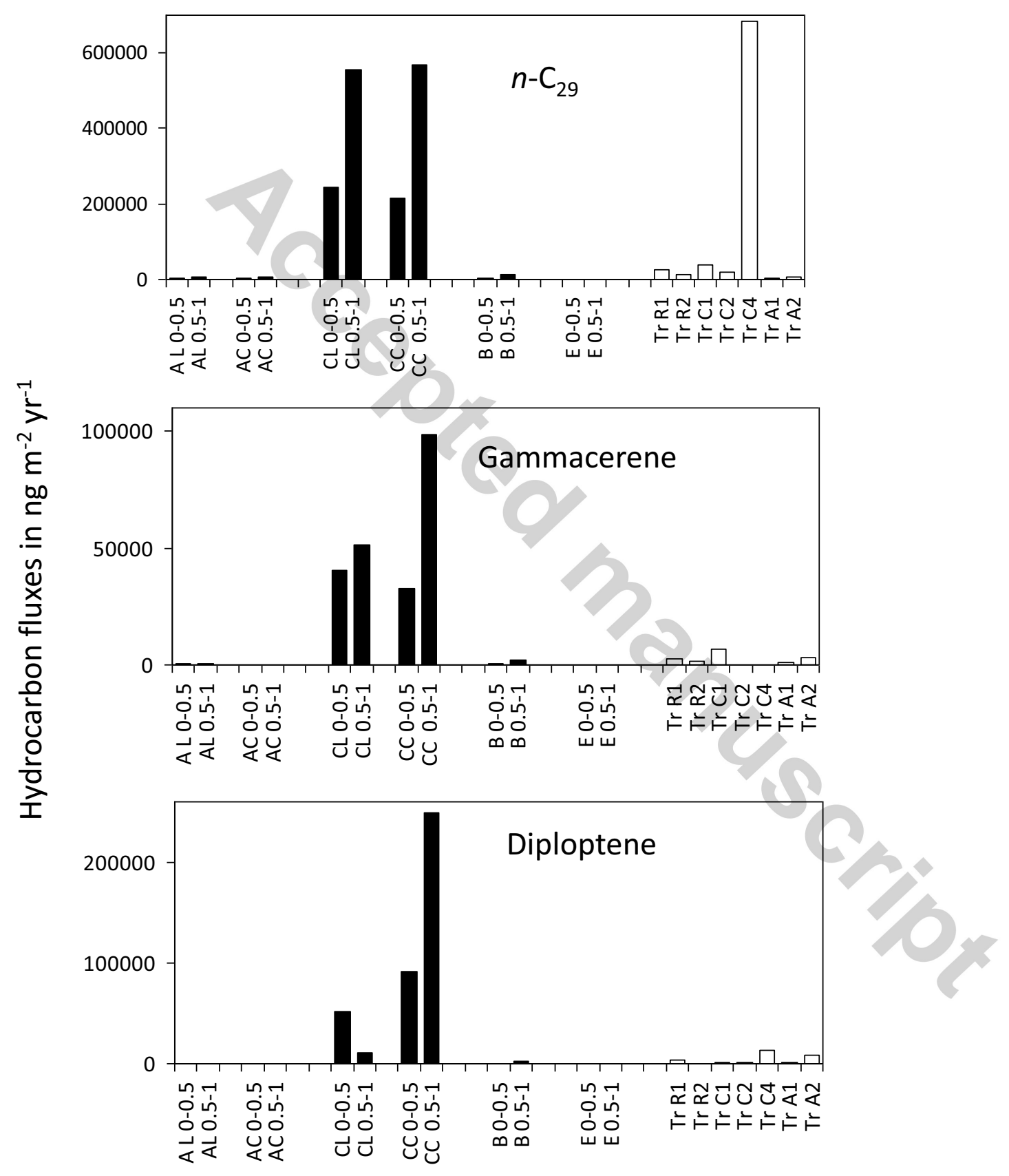

Figure 12 